\title{
GURGA CHIYA AND TEPE MARANI: NEW EXCAVATIONS IN THE SHAHRIZOR PLAIN, IRAQI KURDISTAN ${ }^{1}$
}

\author{
By DaVid Wengrow, Robert CARTER, GAReth Brereton, MARy SHEPPERSON, \\ SAmi JAMil Hamarashi, SABer AHMEd SABer, ANDREw Bevan, Dorian Fuller, \\ Helen Himmelman, Hanna SosnowsKa and Lara GonZalez CARretero
}

Gurga Chiya and Tepe Marani are small, adjacent mounds located close to the town of Halabja in the southern part of the Shahrizor Plain, one of the most fertile regions of Iraqi Kurdistan. Survey and excavation at these previously unexplored sites is beginning to produce evidence for human settlement spanning the sixth to the fourth millennia, c. 5600-3300 cal. B.c. In Mesopotamian chronology this corresponds to the Late Neolithic through to Chalcolithic periods; the Halaf, Ubaid, and Uruk phases of conventional culture history. In Iraqi Kurdistan, documentation of these periods - which witnessed many important transformations in prehistoric village life - is currently very thin. Here we offer a preliminary report on the emerging results from the Shahrizor Plain, with a particular focus on the description of material culture (ceramic and lithic assemblages), in order to establish a benchmark for further research. We also provide a detailed report on botanical remains and accompanying radiocarbon dates, which allow us to place this new evidence in a wider comparative framework. A further, brief account is given of Late Bronze Age material culture from the upper layers at Gurga Chiya. We conclude with observations on the significance of the Shahrizor Plain for wider research into the later prehistory of the Middle East, and the importance of preserving and investigating its archaeological record.

\section{Introduction}

With a Mediterranean climate and 700-900 millimetres of annual precipitation, the Shahrizor Plain - which lies in Sulaimaniyah Province, close to the town of Halabja - is one of the most fertile areas of Iraqi Kurdistan. This preliminary report documents new archaeological fieldwork in this relatively unexplored part of the Middle East. The focus of these new investigations is on the later prehistory of the Shahrizor, between the sixth and fourth millennia B.C. In broader regional terms this corresponds to the long period between the establishment of Neolithic farming settlements and the emergence of the earliest cities, although the nature of these processes in Iraqi Kurdistan remains very poorly documented.

In neighbouring parts of the Middle East, the periods in question have traditionally been divided into a series of broad cultural phases (Halaf, Ubaid, Uruk), reflecting associated changes in material culture and settlement patterns. In recent decades the utility of these broadly defined phases for any wider reconstruction of social evolution has been repeatedly brought into question. Partly this is the result of sustained research in areas such as the Syrian Euphrates and southern Turkey, bringing to light the complexity of local developments in village, and later urban, life and leading to a wider

\footnotetext{
${ }^{1}$ The Shahrizor Prehistory Project is funded by UCL Qatar and University College London, and was initiated through a grant awarded by the UCL Grand Challenge scheme for Intercultural Interaction. Our sincere thanks to Abubakir O. Zainadin (KRG Directorate General of Antiquities) and Hashim Hama Abdullah (Sulaimaniyah Museum) for their collaboration on this project; to Thilo Rehren, Stephen Shennan, Mark Altaweel, Eleanor Robson, and Hamish de Bretton Gordon for their support and expertise; to Abdlqadir Shadi for sharing his knowledge of local history in the Halabja area; and to the residents of Bakr Awa and Sirwan, without whose enthusiastic participation this project would not have been possible.

In addition to the named authors, core project staff for the
}

seasons reported here included Nadia Knudsen (Finds Manager and Illustrator), Dr. Eleni Asouti (University of Liverpool) and Wioletta McGilvray (Environmental Archaeology), Flavia Ravaioli and Renata Peters (Conservation), Stephanie Emra, Laura Green, Lana Haddad, and Michael Lewis (Excavators and Finds Assistants). We are grateful to them all for their patience, good humour, and many hours of work. Our final thanks go to Simone Mühl, whose pioneering fieldwork and generous collegiality laid foundations for our project; to Karen Radner for the initial impetus to work in Iraqi Kurdistan; and above all to Kamal Rasheed Raheem, Director of Antiquities and Heritage, Sulaimaniyah, for his tireless efforts in support of our expedition, and for his warm hospitality. 


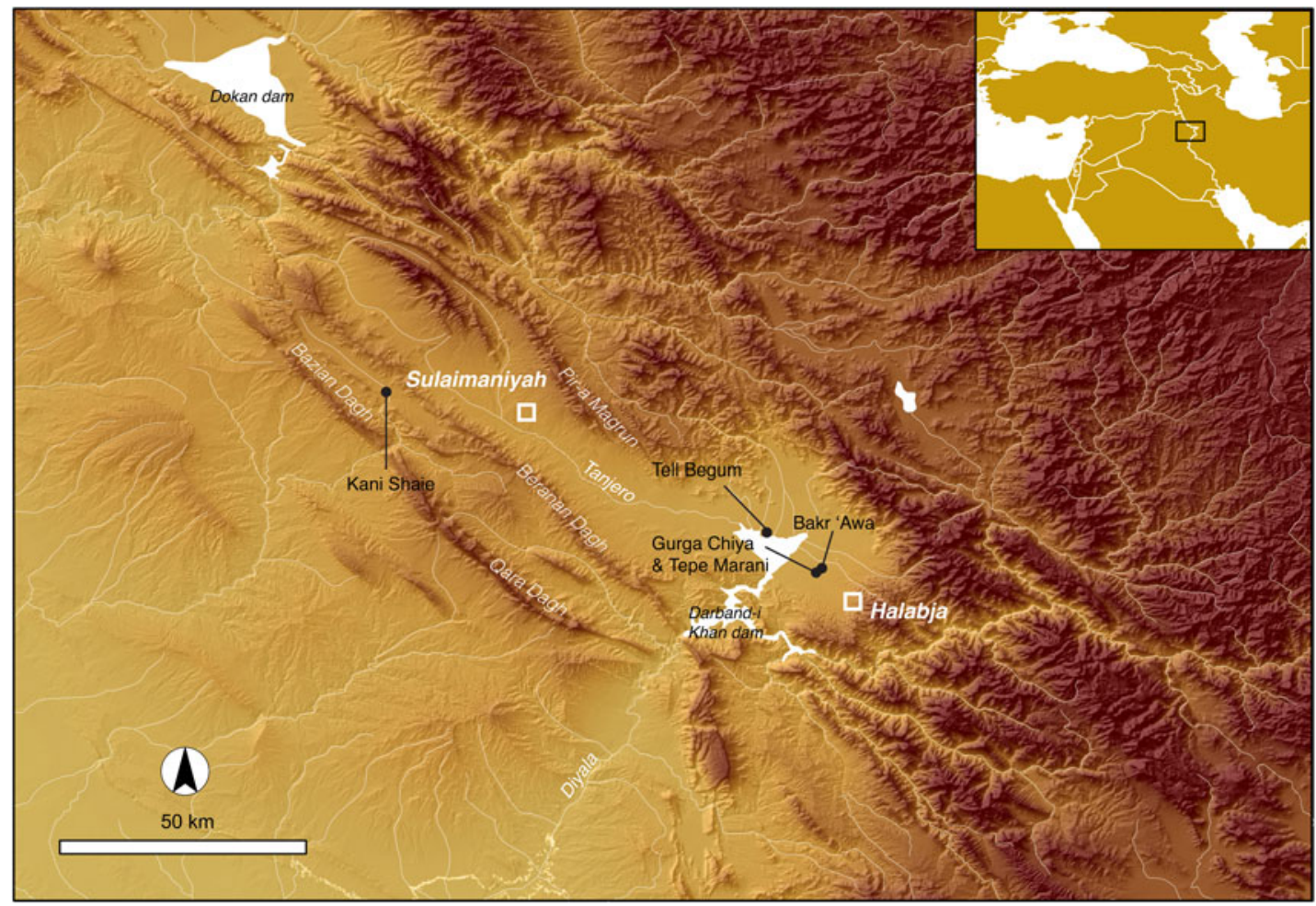

Fig. 1 Gurga Chiya and Tepe Marani in their regional setting (map created by A. Bevan)

reformulation of key research questions (summarised in Baird 2012; Campbell 2012; Carter and Philip 2010; Schwartz and Akkermans 2003).

Owing to protracted periods of warfare and political instability, Iraqi Kurdistan remained largely isolated from these wider research agendas and debates in the later twentieth century. A primary aim of the current project is to help rectify this situation by building up a detailed record of human settlement and associated material culture in the later stages of the Neolithic and Chalcolithic periods, situated within a wider archaeological exploration of the surrounding landscape. Given its agricultural potential, and its location astride key passes into the western Zagros and the Diyala Valley, the wide open plain of the Shahrizor seemed a logical place to begin.

\section{The sites and their geographical setting}

Gurga Chiya and Tepe Marani are small, adjacent mounds in the southern part of the Shahrizor Plain (Fig. 1). Viewed from the site of Gurga Chiya, the surrounding plain is framed by a number of prominent landmarks. To the southeast lies the town of Halabja, beyond which the foothills of the Zagros Mountains rise toward the border between Iraq and Iran. To the northeast the view is dominated by the site of Bakr Awa, a major ancient settlement (Miglus et al. 2011; 2013), beyond which runs the modern road between Halabja and Sulaimaniyah. To the north-west lies the Darband-i Khan Dam Lake, established on the former headwaters of the Diyala River in the 1950s, where the waters of the Tanjero and other, smaller tributaries once joined the Sirwan (Upper Diyala), then flowing south through the Hamrin mountain range to join the Tigris below Baghdad. Numerous archaeological mounds of widely varying sizes are visible in the vicinity, extending east across the Shahrizor beyond Bakr Awa towards the highlands, and west up to the fringes of the lake, beneath which an estimated seventy archaeological sites, as well as the remains of some twenty early twentieth century villages, are now submerged (see Mühl 2010; 2013).

Gurga Chiya and Tepe Marani lie outside the area periodically flooded by the lake, in a section of the plain that has been under increasingly heavy cultivation since the late 1960s, when tractors were 
introduced, followed in the 1970s by centralised redistribution of arable land between the surrounding villages. An estimated century ago a waterwheel and mill —of which no trace is now visible-were located on Gurga Chiya together with a number of houses, the foundations of which were long ago cleared for ploughing (Abdlqadir Shadi, pers. comm.). The modern village of Gurga Chiya lies a short way to the north-west, along a road leading to the steep mound of Tell Qortas, on the margins of the Darband-i Khan Lake. Prior to the dam's construction the region provided rich fishing yields, and during the period of British Administration (1920-32) a bridge had crossed the Sirwan where it flows downstream past the lower reaches of the Qara Dagh range (ibid.). Prominent archaeological sites in the area around the Darband-i Khan Lake were used for military purposes during the Iran-Iraq War (1980-88). Perimeters for gun emplacements are visible as raised earthen banks on the summits of ancient tells, and long mounds of earth - used as cover for advancing units-are widespread.

The foothills of the nearby Zagros Mountains were once heavily forested. Pollen sequences from the wider Irano-Anatolian region indicate relatively slow commencement of tree growth after the end of the last Ice Age, with marked acceleration in the middle Holocene (from c. 4000 B.C.; Asouti and Kubukcu 2014). Sheep, goat, and cattle are currently grazed in the immediate vicinity of the sites, making use of a wadi that erodes the eastern profile of Gurga Chiya, and wild boar are still occasionally hunted in the uplands. The history of sheep and goat herding in this region extends back to the initial domestication of these species (Zeder and Hesse 2000; Matthews et al. 2013). Both ancient and modern herding practices in this region are often characterised as "transhumant". This, however, is a gloss on the complex history of interactions between pastoralists, villagers, and urban centres on the fringes of the Zagros (see, for example, Fredrik Barth's characterisation of the Jaf tribe's seasonal movements between Bakr Awa and the Penjwin mountains in the early-mid twentieth century; Barth 1953; and also Potts 2014 for a broader historical view). Altaweel et al. (2012) describe the wider geographical setting of the Shahrizor Plain in further detail, and review major historical sources for the region's development over the last five millennia.

\section{Archaeological research in the Shahrizor Plain}

The history of modern archaeological fieldwork in this area falls into two parts: survey and excavation by Iraqi archaeologists in the context of dam construction (1951-61), and work undertaken by the Sulaimaniyah Directorate of Antiquities and Heritage over the past decade. International projects have been active for some years, including large-scale excavation on the high tell and "lower city" of Bakr Awa (Miglus et al. 2011; 2013), where the known range of archaeological strata extends from the Uruk period to Islamic times. The earlier prehistory of the Shahrizor was known from surface survey and limited exposures at a handful of sites (summarised in Altaweel et al. 2012: 18; and see also Mühl 2013). In 1960 a large sounding at Tell Begum, north of Darband-i Khan, revealed floors and house foundations dated by associated pottery to the Late Neolithic and Early Chalcolithic periods (Hijjara 1997: 127-29). Further evidence of these phases derives from recent work by the Sulaimaniyah Directorate at the sites of Greza and Tanjero, north-west of Arbat, and new work by the University of Leiden has recently commenced at Tell Begum (Nieuwenhuyse et al. 2016).

The potential for further research on the prehistory of the Shahrizor Plain has been greatly clarified by a regional survey undertaken since 2009 by Mühl $(2010 ; 2013)$, which laid foundations for current excavations at the Early Neolithic site of Bestansur (Nieuwenhuyse et al. 2012; and work now ongoing by the Central Zagros Archaeological Project, University of Reading). Mühl's survey, which identified ceramics of the Chalcolithic period at Gurga Chiya, also provided the basis for the Shahrizor Prehistory Project-a collaboration of the UCL Institute of Archaeology, UCLQatar, and the Sulaimaniyah Directorate of Antiquities and Heritage-which includes excavations there and at Tepe Marani.

\section{Gurga Chiya and Tepe Marani: the sites and their location}

Gurga Chiya (Figs. 2 and 3) is a steep-sided, multi-period mound covering approximately one hectare and rising twelve metres above the surrounding field systems. Traces of "hollow ways" (cf. Wilkinson 


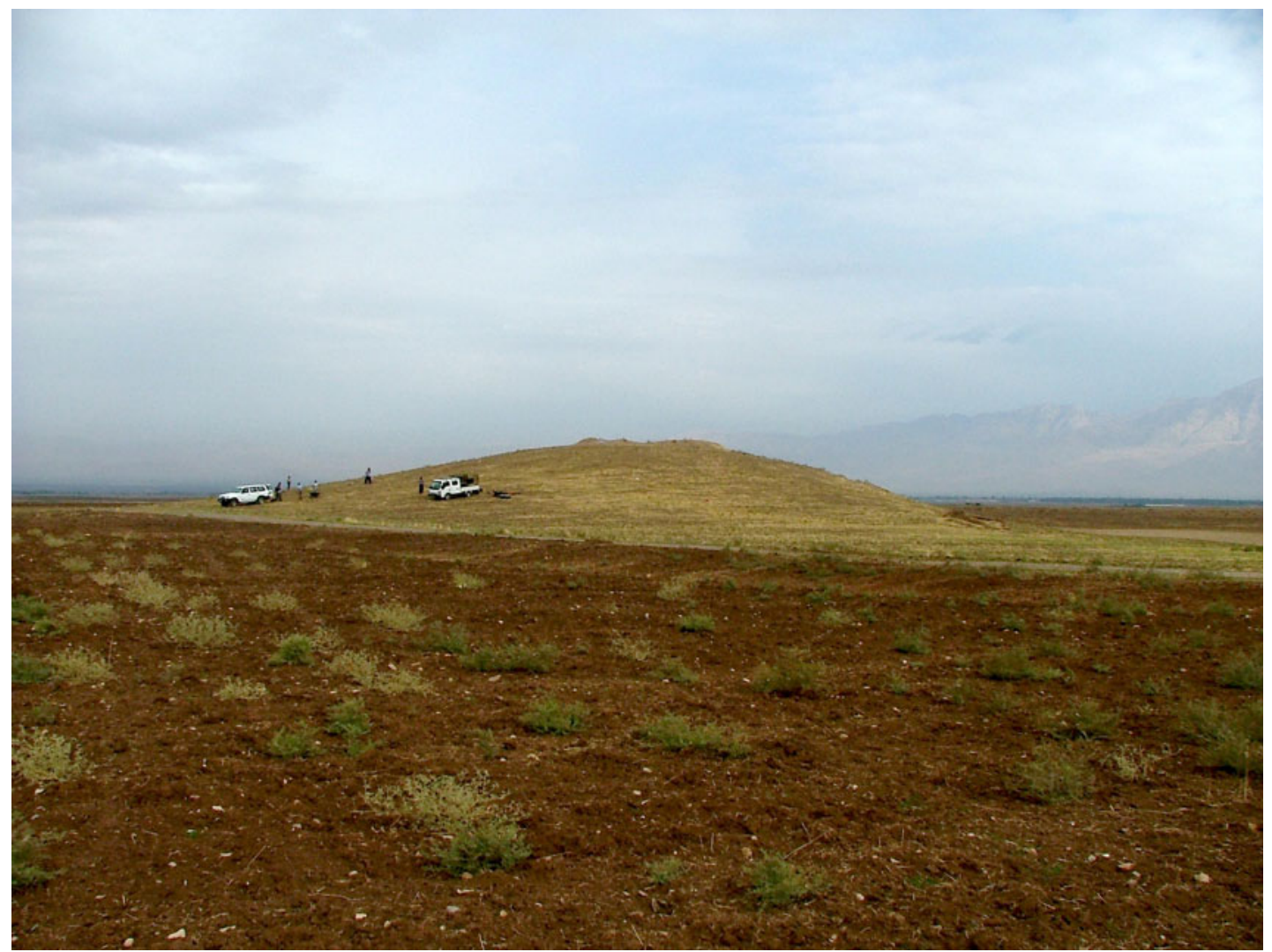

Fig. 2 Gurga Chiya, viewed from the south-west (photograph by G. Brereton)

2003) departing from the site to the west and north are clearly visible on CORONA satellite images, but their dates of formation are unknown (Mühl, pers. comm.). Significant quantities of pottery, recovered from slope wash deposits on the north and south faces of the mound during the pilot season (Fig. 3, Trenches GC-A and GC-C), indicate the existence of a Late Bronze Age settlement. Our work has since focussed on the mound's west face (GC-E and GC-F), where deposits of the Uruk and Late Chalcolithic periods, and associated architecture, were uncovered close to the surface of the mound.

Tepe Marani is a low mound lying less than half a kilometre south of Gurga Chiya. Its shallow profile and location on a natural rise make it almost imperceptible to the naked eye. The contours of the site, as revealed by DGPS survey (Fig. 3), cover $c$. 0.7 hectares. It has been extensively ploughed in recent decades and Late Neolithic (Halaf-related) pottery is relatively abundant on the surface, including painted wares. Pottery of this kind was rarely noted in recent surveys of the Shahrizor Plain (see Mühl 2013: 83-90), but the preliminary results from Tepe Marani indicate that remains of this period, including architecture, may in fact be preserved on shallow mounds that have survived the impact of modern farming.

Gurga Chiya and Tepe Marani are located in a part of the Shahrizor that might seem inauspicious for prehistoric research. It is here that the Tanjero River, having first followed a more constrained passage between the Pir-a Magrun and Beranan Dagh ranges, enters a wide plain fanning outwards towards the Zagros foothills. Accordingly the accumulation of alluvial deposits is likely to be most heavy in this eastern part of the plain, burying prehistoric sites below some metres of sediment. However, the uniformity of the present-day plain — with its rich, deep soils - is deceptive: a product of two or more millennia of stable soil formation, hastened by deforestation, intensive grazing, and extensive agriculture. 


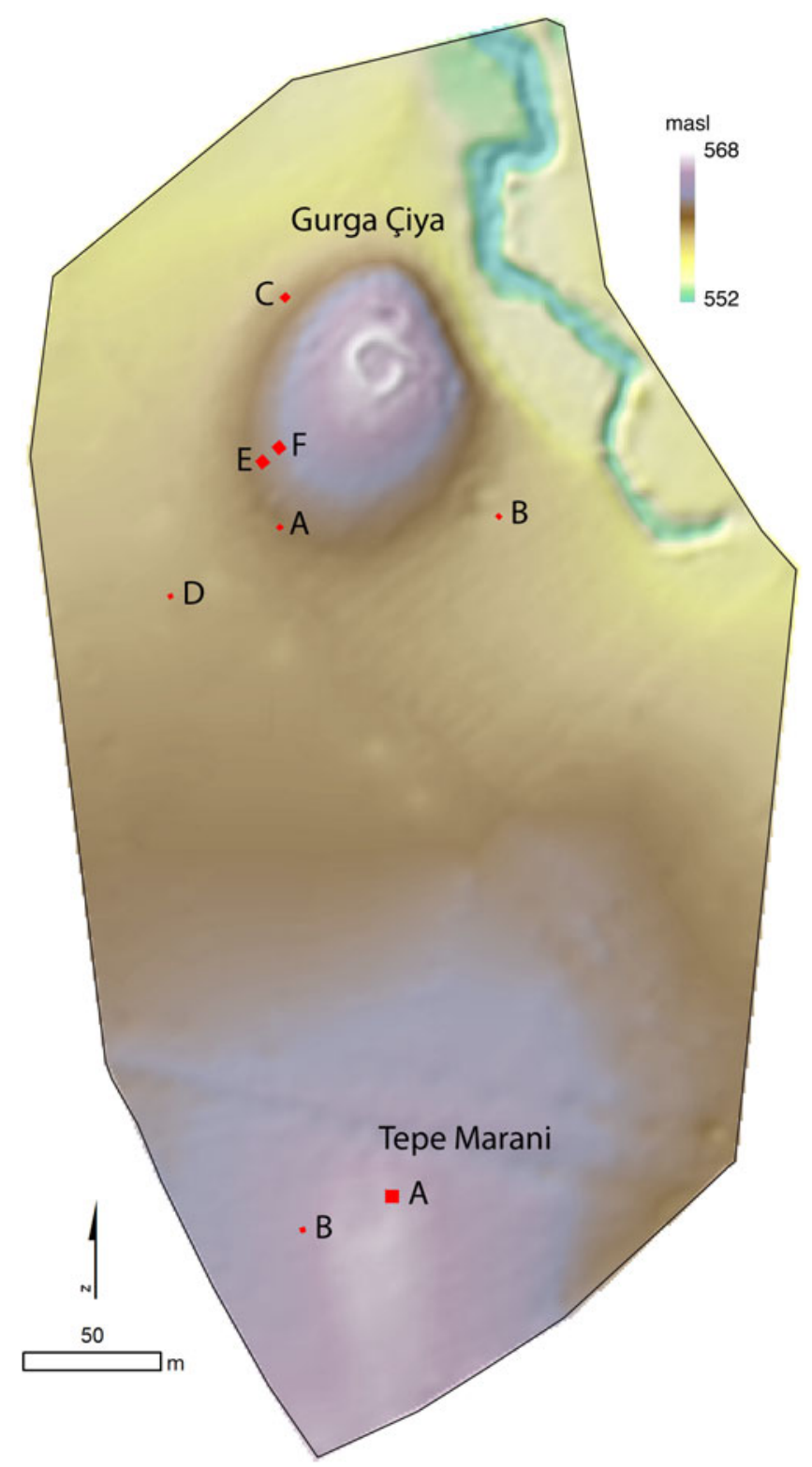

Fig. 3 Digital Elevation Model of Gurga Chiya and Tepe Marani showing location of main trenches (TM-A, TM-B; GC-C, GC-E, GC-F) and test pits (GC-A, GC-B, GC-D; map created by A. Bevan; edge of image = edge of area surveyed)

Deep geological cores drilled in the vicinity of Gurga Chiya indicate a complex mosaic of early and middle Holocene environments. Arable soils would have been much less evenly distributed and were most likely interspersed with grassland, woodland, areas of marsh, and riparian gallery forest. Especially significant, in terms of site preservation, is the emerging evidence for Pleistocene terraces overlooking perennial and seasonal watercourses. This suggests the former existence of an undulating land surface with markedly raised areas, where evidence for early human settlement has escaped the effects of sedimentation (Altaweel et al. 2012: 4-8). Gurga Chiya and Tepe Marani, and also nearby Bakr Awa, appear to be located on terraces of this kind.

To date, two phases of archaeological fieldwork have been undertaken at Gurga Chiya (GC) and Tepe Marani (TM). During a pilot season (4-9 May, 2012) the latter site was identified, test trenches were excavated at Gurga Chiya, and a DGPS survey of both sites was commenced by Bevan (Fig. 3). 
A longer season (2-27 May, 2013) saw the establishment of two trenches on Tepe Marani (supervised by Brereton) and four trenches on and around Gurga Chiya (supervised by Shepperson). Their purpose was to identify the location of late prehistoric deposits and test for the possible extension of the mound below the modern alluvium. One test trench dug into the cultivation, approximately 50 metres to the west of the tell (GC-D), produced a small assemblage of chipped stone, as well as highly eroded fragments of coarse pottery and bone fragments at a depth of $c$. 2 metres, but no extension of the mound was detected in this direction.

On the mound itself, and on Tepe Marani, sampling strategies were implemented for the recovery of environmental remains and micro-artefacts. These included on-site dry sieving (to 5 millimetre mesh), flotation, and fine sorting of heavy residues (down to 1 millimetre). On-site conservation of archaeological materials was undertaken by Ravaioli in the nearby village of Bakr Awa using locally sourced materials; and interviews were conducted with local residents concerning the recent history of the area. Results of this work are summarised below by broad chronological phases: Late Bronze Age, Chalcolithic, and Late Neolithic; comparisons are drawn with known sites and assemblages across the wider Middle East to provide a context for our findings; and we conclude with some preliminary interpretations and suggestions for further research.

\section{The Late Bronze Age at Gurga Chiya}

In the course of identifying areas with accessible prehistoric strata, significant quantities of Bronze Age pottery and chipped stone were recovered from Gurga Chiya. Their original occupation horizon appears to be high on the mound, and the excavated levels largely consist of redeposited material distributed across much of the lower part of the site. This is particularly evident in GC-C, located on the lower (north-western) slope, where Bronze Age ceramics were found within a deep deposit of mixed debris washed down from higher up the mound. Below this a series of further substantial deposits produced medium-large sherds of similar date. The concentration of debris suggests a phase of rapid building decay, possibly following the abandonment of all or part of the site.

Extending into the corner of Trench $\mathrm{C}$, and directly below these pottery-rich redeposited layers, was a well-preserved oven or clay-lined hearth with heavily fired walls. Sampling of its contents produced a rich botanical assemblage, described further below. Single lentil and barley seeds from within this feature yielded radiocarbon dates calibrated to 1390-1120 cal. B.C. at 2 sigma (Beta$368811,3010 \pm 30$ B.P.) and to $1420-1260$ cal. B.C. at 2 sigma (Beta-368812, $3080 \pm 30$ в.P.) respectively (Table 1). The ranges are relatively long owing to the nature of the calibration curve at this point, but when combined can be slightly narrowed to $1393-1227$ B.C. at 2 sigma (OxCal v.4.2.3). Sealed below the oven and an associated mud-brick wall or platform were two further layers of slope-wash containing further Late Bronze Age pottery and chipped stone tools.

In total some forty-nine pieces of chipped stone could be securely ascribed to the Late Bronze Age horizon at Gurga Chiya. A sample is illustrated in Figure 4. All but three are made from (presumably local) chert and fine-grained limestone, among them two fragments of blades including a sickle blade (Fig. 4: 6,7), two retouched flakes, one large denticulate (Fig. 4: 2), one borer (Fig. 4: 5) and one awl (Fig. 4: 3), one fragment of a flake core, with several debitage platforms, and one core tablet (Fig. 4: 1). Three obsidian artefacts were found: a backed blade fragment (Fig. 4: 10), a micro-burin (Fig. 4: 8) and one splintered piece (Fig. 4: 9). The rest of the assemblage consists predominantly of flakes, several flake-blades, fragments of nodules and angular shatter.

Most of the Late Bronze Age pottery from Gurga Chiya was recovered from GC-C, with quantities also recovered from the test pit on the southeast side of the mound (GC-B). As described above, the majority was redeposited in slope-wash originating from a formerly substantial LBA occupation on top of the mound. Similar ceramic material was associated with the in situ tannur and built feature near the bottom of GC-C. Recovered vessels consist chiefly of large- and medium-sized storage jars in a soft brown fabric with medium to fine chaff temper (Fig. 5: 1-35), many of which bore finger-impressed or incised decoration on appliqué cordons. Sieves of the same ware were also found (Fig. 5: 57) as well as bowls of various sizes (Fig. 5: 36-40). Also present was a less common cream ware (Fig. 5: 41-46) used for medium sized jars. Small rims and knob-bases, likely to be associated with jars and/or beakers, were found in a fine brown fabric (Fig. 5: 47-55). 
TABle 1: AMS dates from Gurga Chiya and Tepe Marani, processed at Beta Analytic

\begin{tabular}{|c|c|c|c|c|c|c|c|c|}
\hline Laboratory Code & Site & Context & Sample Weight & Sample Material & Species identification & $\begin{array}{l}\text { Uncalibrated } \\
\text { dates BP }\end{array}$ & $\begin{array}{l}\text { Calibrated dates } \\
2 \text { sigma }\end{array}$ & Comments \\
\hline Beta - 368811 & Gurgachiya & 210 & $0.00800 \mathrm{~g}$ & charred seed & Lens culinaris & $3010 \pm 30$ & 1390-1120 cal. BC & \\
\hline Beta - 368812 & Gurgachiya & 210 & $0.01105 \mathrm{~g}$ & charred grain & Hordeum vulgare & $3080 \pm 30$ & $1420-1260$ cal. BC & \\
\hline Beta -368808 & Gurgachiya & 304 & $0.00752 \mathrm{~g}$ & charred grain & Lens culinaris & $5290 \pm 40$ & 4240-3990 cal. BC & $\begin{array}{l}\text { Residual occurrence } \\
\text { from deeper level? }\end{array}$ \\
\hline Beta - 368809 & Gurgachiya & 304 & $0.00658 \mathrm{~g}$ & charred grain & Hordeum vulgare & $4740 \pm 30$ & $3640-3370$ cal. BC & \\
\hline Beta -368798 & Marani & 5012 & $0.00960 \mathrm{~g}$ & charred seed & Vicia ervilia & $6600 \pm 40$ & $5620-5480$ cal. BC & \\
\hline Beta - 368799 & Marani & 5012 & $0.02933 \mathrm{~g}$ & charred grain frags & Hordeum vulgare & $5280 \pm 30$ & $4240-3990$ cal. BC & Intrusive grain? \\
\hline Beta - 368801 & Marani & 6002 & $0.02886 \mathrm{~g}$ & charred seed & Lathyrus sativus & $6370 \pm 40$ & $5480-5230 \mathrm{cal}$. вС & \\
\hline Beta - 368802 & Marani & 6002 & $0.00791 \mathrm{~g}$ & charred grain & Triticum dicoccum & $6290 \pm 30$ & $5320-5210$ cal. BC & \\
\hline Beta -368805 & Marani & 6002 & $0.02173 \mathrm{~g}$ & charred grain & Triticum dicoccum & $2040 \pm 30$ & $170 \mathrm{BC}-50 \mathrm{AD}$ & Intrusive grain? \\
\hline Beta - 368804 & Marani & 6003 & $0.00274 \mathrm{~g}$ & charred seed frags & VicialLens culinaris & $480 \pm 30$ & $1400-1460 \mathrm{AD}$ & Intrusive fragments? \\
\hline
\end{tabular}



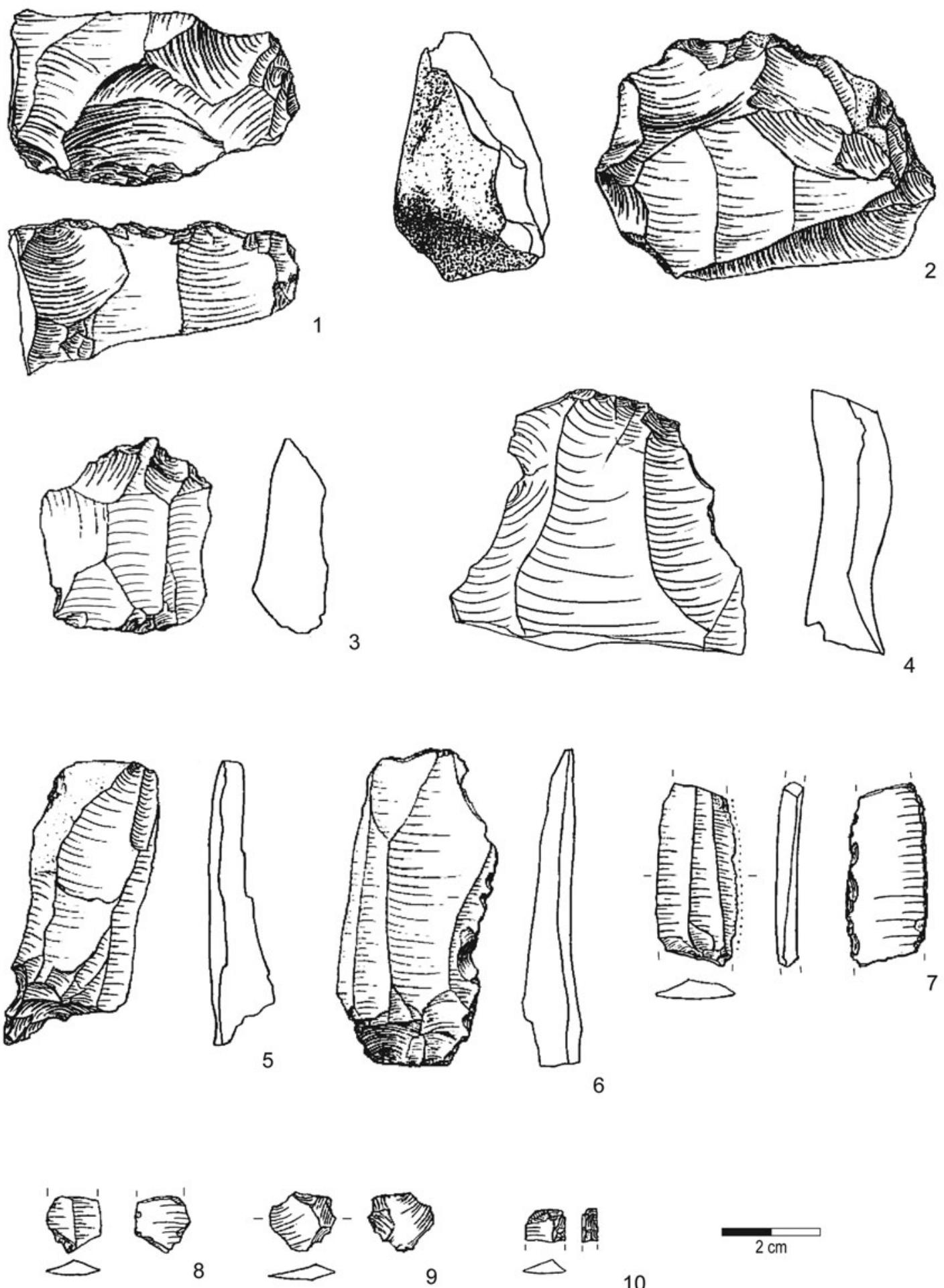

10

Fig. 4 Chipped stone artefacts of the Late Bronze Age from Trench C at Gurga Chiya (drawn by H. Sosnowska) 


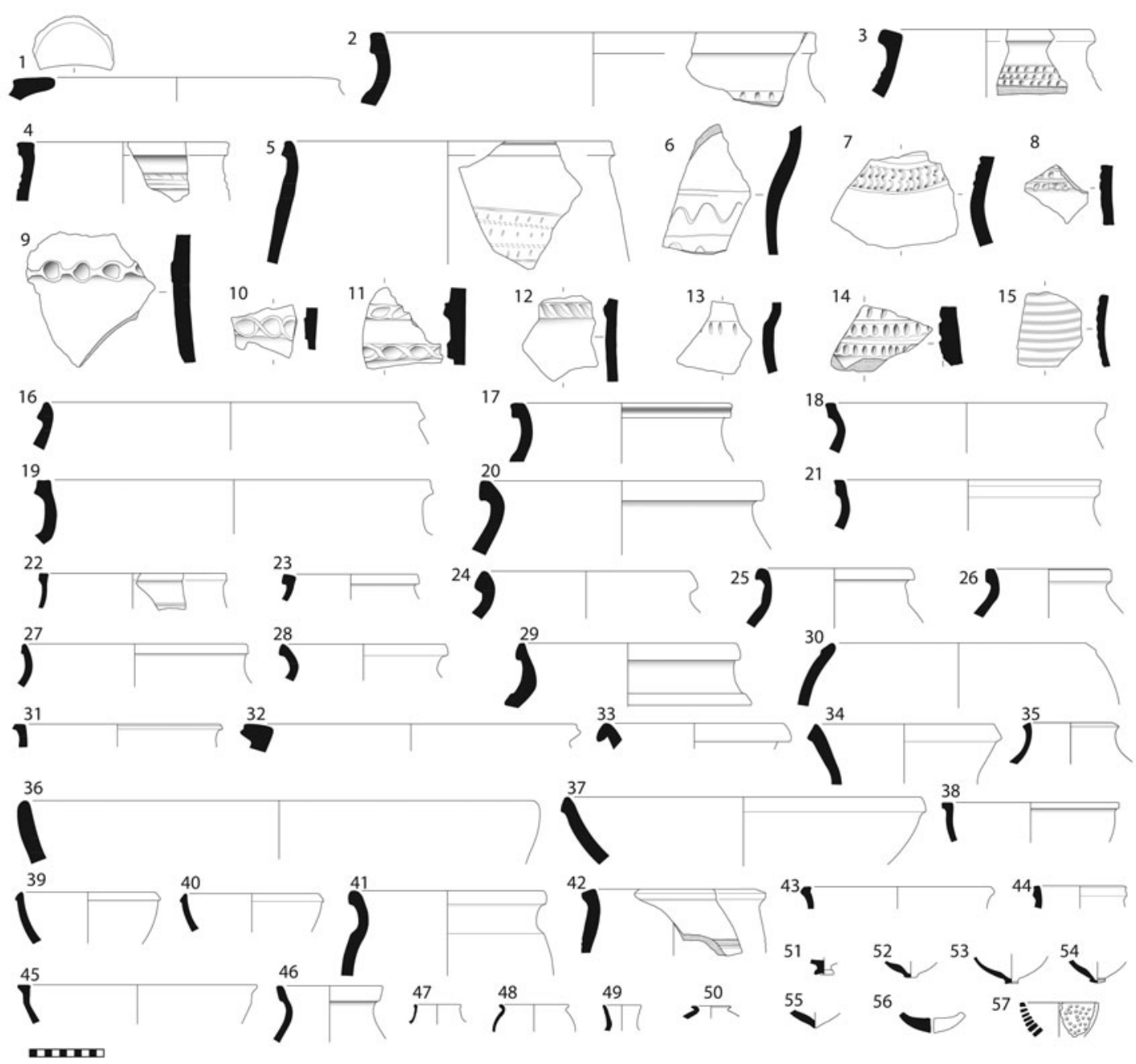

Fig. 5 Late Bronze Age pottery from Gurga Chiya: 1-40, 56-57: brown fabric with and grey core and medium chaff temper. 41-46: cream fabric with medium chaff temper. 47-55: fine brown fabric

Formal parallels for the knob bases, sieves, and jars with incised and impressed decoration are found at LBA sites across northern Mesopotamia, from Yorgan Tepe in the east (Starr 1937-39, pls. 63-68, 77, 95-96) to Tell Brak in the west (Oates et al. 1997, fig. 184: 57-60, fig. 194, fig. 212: 614-15, fig. 213: 627). Mühl (2013: 172-98) provides further discussion of LBA ceramic assemblages east of the Tigris, and outlines their wider social and economic contexts. Absolute dating of the assemblage derives from radiocarbon samples, obtained from the tannur in GC-C (early fourteenth to late thirteenth centuries B.C.; see above).

\section{The Uruk Period at Gurga Chiya}

Two $4 \times 4$ metre trenches (E and F), located 4 metres apart on the western slope of Gurga Chiya, produced a sequence of artefact-rich deposits and structural remains spanning the fifth and fourth millennia B.C. In both cases a poorly preserved upper horizon, truncated by ploughing, contained the bottom parts of fired clay ovens (Fig. 6) of which there were four in total, ranging from 50 to 60 centimetres in diameter at point of survival. The lack of any kind of built structure around these oval installations suggests they were constructed in pits dug into older deposits. One contained bevel-rim bowl fragments and no later pottery has been identified in their fills. We tentatively conclude that these features date within the Chalcolithic, and are only slightly later than the Middle Uruk deposits into which they were dug. 

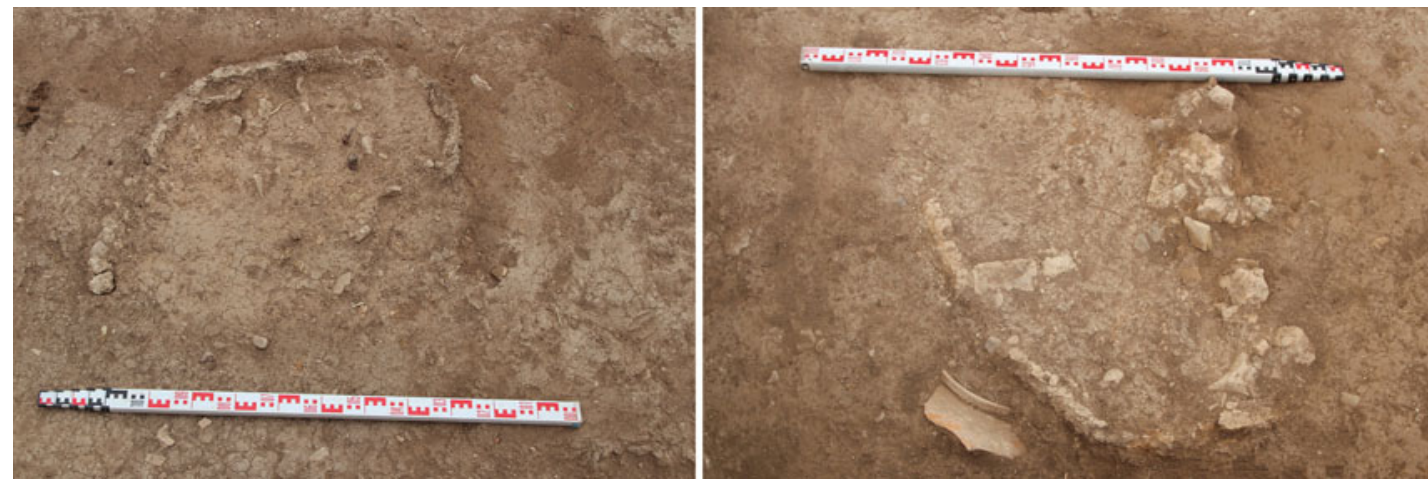

Fig. 6 Uruk-period ovens with fired clay walls in the upper levels at Gurga Chiya, Trenches E (left) and F (right)

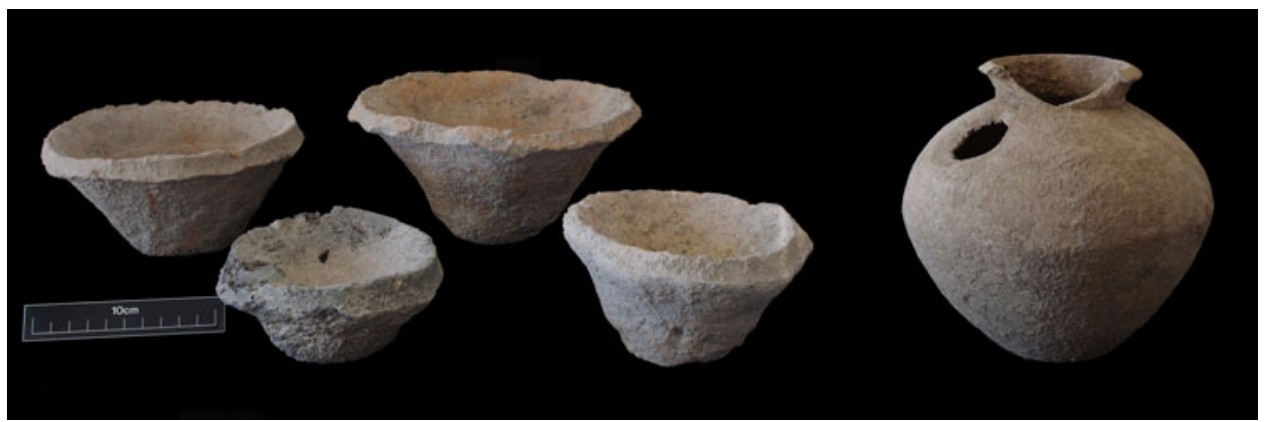

Fig. 7 Left: Bevelled-rim bowls. Right: spouted jar from the Middle Uruk deposit at Gurga Chiya (Trench F; photograph by G. Brereton)

The higher of the two trenches (GC-F) contained a dense deposit of Middle Uruk ceramics, chipped stone and other material covering much of its surface. This deposit lay below the oven layer, and directly above a stone foundation wall running between the east- and north-facing sections. The pottery deposit contained bevel-rim bowls of widely varying sizes and fabrics (Fig. 7: left; Fig. 8: 1-3) many of them complete or near complete, suggesting this material lay at its original point of deposition. Given the hypothesis that these bowls may have been used to manufacture pot-baked bread (most recently, Goulder 2010, with further references), it is tempting to see an association between the dense pottery deposit and the overlying ovens; although the lack of any direct stratigraphic association must be borne in mind.

Globular jars (Fig. 8: 4-5) with rounded or everted rims were also common within the Middle Uruk deposit. They were typically made in grey burnished wares, sometimes with pierced noselugs and a rope-incised cordon or slashed incisions running around the shoulder. Also present were straight-spouted vessels (Fig. 7: right; Fig. 8: 9-10), fine cups (Fig. 8: 12) and red slipped and burnished jars with rope-impressed banding and applique nose lugs (Fig. 8: 7). The assemblage as a whole compares well with that from the Middle Uruk levels (5-7) at Sheikh Hassan (Boese 1995), suggesting a mid-fourth millennium date (i.e., Late Chalcolithic 3-4). The same deposit also produced a small number of sherds showing closer affinities to northern Ubaid wares (not depicted). These most likely derive from earlier phases of occupation at Gurga Chiya. This probability is also reflected in two radiocarbon dates taken from the soil matrix of the large pottery deposit. While one gives a Middle Uruk/LC 4 date calibrated to 3630-3400 cal. B.C. at 2 sigma (Beta 368809, $4740 \pm 30$ B.P.), consistent with the majority of the pottery, the other is considerably earlier at 4240-3950 cal. в.C. at two sigma (Beta 368808, $5290 \pm 40$ в.P.), suggesting the presence of residual material brought up from lower layers, as is also the case in the upper fills of GC-E. 

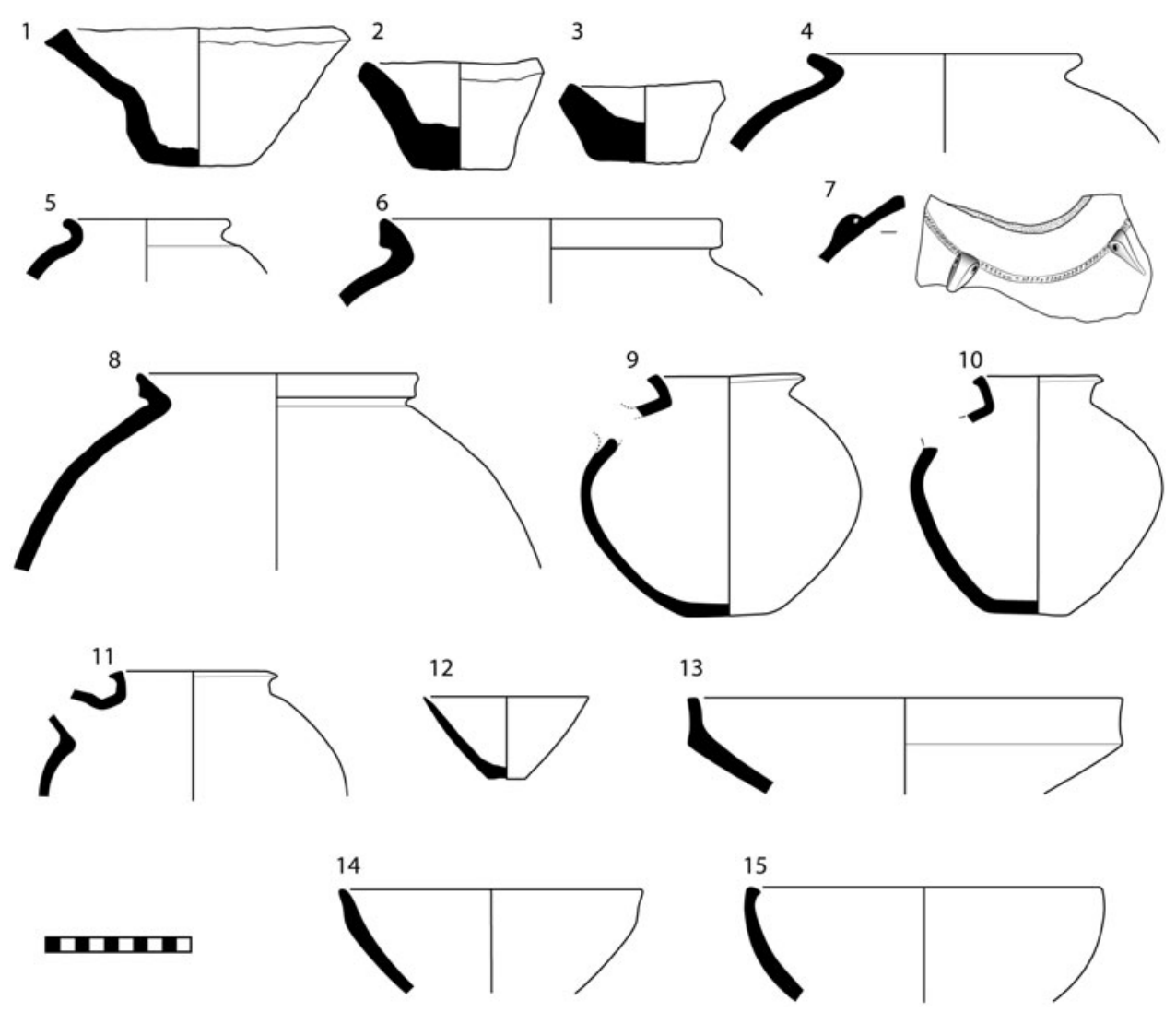

Fig. 8 Material from the Middle Uruk pottery scatter and associated levels (Trench F). 1-3: BRBs with coarse vegetal and grit temper; no. 3 has one very large grey grit. 4-6: grey burnished ware with medium-fine vegetal and grit temper. 7-9, 13-15: red slipped and burnished ware with medium-fine vegetal and grit temper. 10-12: fine brown ware; no. 12 has scraped bottom

Of the chipped stone tools ascribed to the Middle Uruk phase of Trench F (Fig. 9) four were made on obsidian, the rest on chert and fine-grained limestone. Only two pieces, a blade and a flake-blade, are retouched (Fig. 9: 4), while the majority of blades show clear traces of use-wear. Seven blades have glossed edges, some of them exhibit double lustre, while three also show bitumen staining (Fig. 9: 7, 8, 10). A prismatic core (Fig. 9: 1) was also recovered, with blade removals around over half of the circumference. One very large blade (Fig. 9: 13), found in Trench E among redeposited Uruk material, can be tentatively classified as a preparatory piece for a "Canaanean blade", of a type also found at Tell Brak (Oates 1993, pl. 5), Hacinebi (Edens 1999), and other Late Chalcolithic sites (cf. Rosen 1983:16).

The removal of the large pottery deposit revealed a compacted soil horizon that contained more Uruk-period sherds as well as an almost complete animal figurine of baked clay (Fig. 10: 2). Excavation halted at this level in 2013, and it is not yet clear whether this layer and its associated figurine should be dated to the Uruk period or a preceding horizon. A copper alloy pin from a fill in Trench E (Fig. 10: 1) can be more securely dated to the mid-fourth millennium B.C. by its direct association with Middle Uruk pottery.

\section{The Late Ubaid Period at Gurga Chiya}

In Trench E, the lower of the two trenches, pre-Uruk levels were reached at a depth of approximately one metre below the surface. A wall foundation of unworked stones was uncovered, forming a corner in the northwest section of trench, parallel to which ran a half-metre-wide band of pebbles extending towards the southern section (Fig. 11). The pebble surface had a raised profile, rendering it unsuitable 

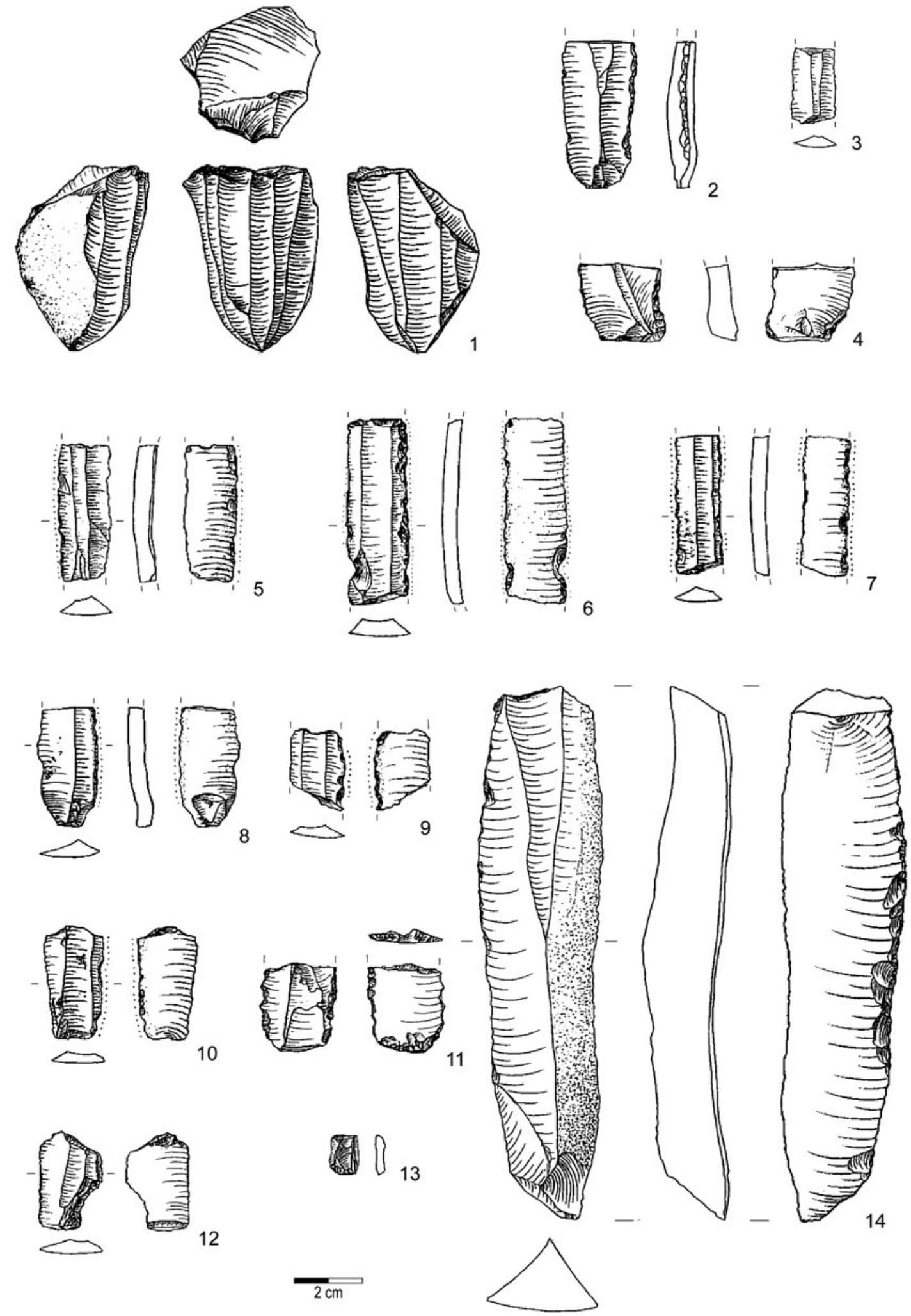

Fig. 9 Chipped stone artefacts of the Middle Uruk period from Gurga Chiya Trench F, Phases 1 and 2 (drawn by H. Sosnowska) 

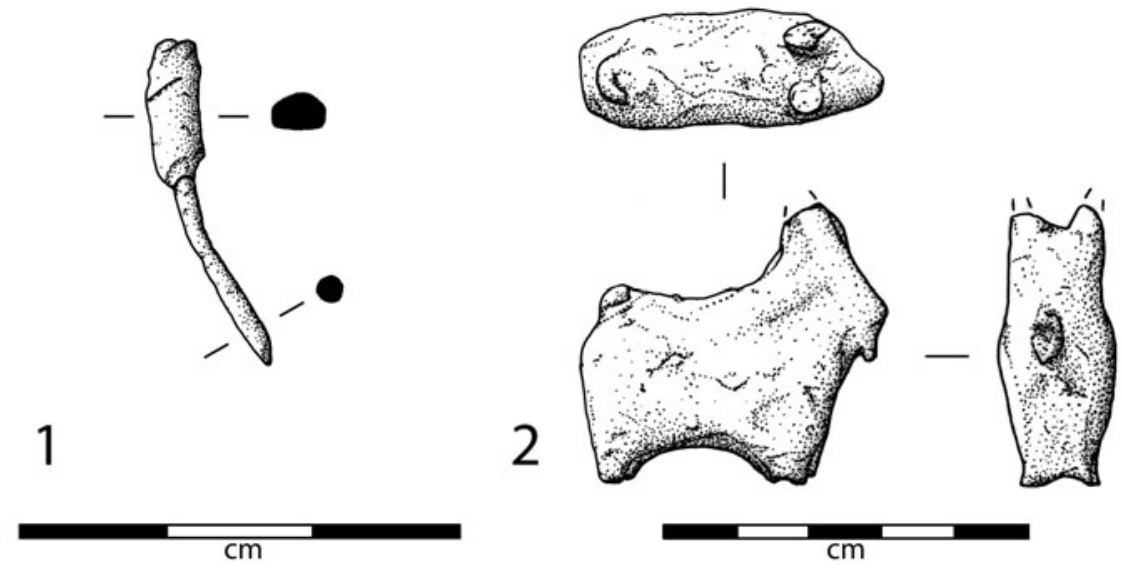

Fig. 10 Left: copper pin (Trench E). Right: baked clay caprid figurine (Trench F; drawn by N. B. Knudsen)

as a drain, and may represent the remnants of a dissolved mud wall or, conceivably, a narrow pathway. To the north and east of this feature, running along the same axis, was a large linear distribution of medium-to-large sized ceramic sherds of the Late Ubaid, or less likely the Late Chalcolithic period (see detailed discussion below). Owing to their common alignment it seems likely that the pottery and pebble feature originally lay on either side of a mud wall that was not visible during excavation. The pottery scatter appears to have consisted mainly of whole vessels crushed in situ, and therefore used and deposited contemporaneously (Fig. 12). Removal of the pebble surface and associated walls at the end of the season revealed a lower layer of occupational debris yielding Late Ubaid style painted pottery and a single fragment of Dalma impressed ware. The latter offers our first clear ceramic evidence for cultural interaction between the Shahrizor and the contemporaneous societies of the western Zagros highlands (cf. Henrickson 1989; and further discussion, below).

Parallels for the ceramics in the linear scatter and the deposit directly below can be found in both Late Ubaid and Late Chalcolithic assemblages elsewhere. The relevant pottery from Gurga Chiya was made mainly of medium and coarse chaff-tempered fabrics, ranging from pale reddish brown to buff and greenish in colour (Fig. 12: 1-3, 7-10, 12-15, 17-22, 24-27). Also present is a range of burnished fabrics, usually brown with a grey core but sometimes greenish, with variable amounts of chaff temper, quartz inclusions and white flecks (Fig. 12: 4-6, 11, 16, 23). Wide variation in fabric colour and inclusions, along with the limited range of forms and sometimes careless execution, points towards a relatively unstandardised ceramic industry, in which utility took priority over aesthetic considerations.

The assemblage includes a significant proportion of "angle-neck jars" (Fig. 12: 1-7; Fig. 13: left). According to Rothman these appear early in the LC2, for example at Hammam VA (Rothman 2002a: 56, fig. 5: p, q, r; Akkermans 1988b, pl. 101: 48-51) and the Gurga Chiya examples have good LC2-3 parallels at Grai Resh (Kepinski 2011, pl. 9.7-16, Pl. 10.1-7). However, they are already common in the Late Ubaid and LC1 periods, for example at Kenan Tepe in the Upper Tigris region, at Tell Madhhur in the Hamrin, at Hammam et-Turkman IVA-D in the Balikh, and at Tell Brak in the Khabur (Parker and Foster 2009, fig. 4; Moon and Roaf 1984, fig. 18; Akkermans 1988a, pl. 75: 96-97, pl. 85.202, pl. 95.294, pl. 96.297; Oates 2012, fig. 7: 3-4). An almost complete, thin-walled, undecorated example (Fig. 13, left), is similar to the finer angle-neck jars found in the Late Ubaid levels at Madhhur, as well as LC1 and LC2 contexts at Gawra XII and Hamoukar (Moon and Roaf 1984, fig. 18: 3; Tobler 1950, pl. 137: 293; pl. 138: 303; Abu Jayyab 2012, fig. 5: 6).

Some of the jars from Gurga Chiya are comb-incised (Fig. 12: 1-2). These do not resemble the comb-impressed wares assigned by Rothman to the LC2, but compare more closely to Late Ubaid pottery from Tepe Gawra ("below XII", therefore likely Gawra XIIA), Khanijdal East, and particularly Tell Madhhur (Tobler 1950, pl. 138: 302; Wilkinson et al. 1996, fig. 10: 57; Moon and 


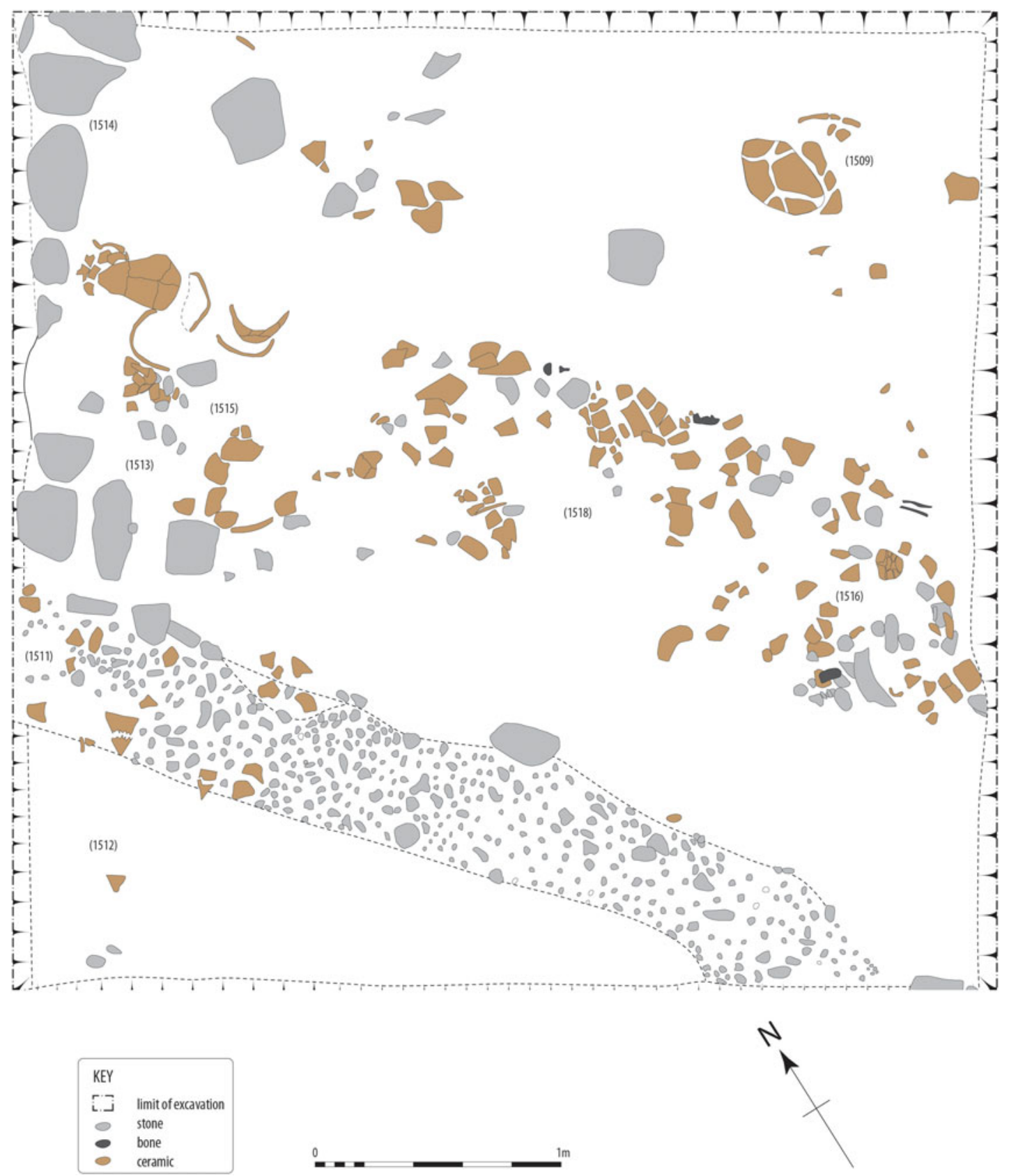

Fig. 11 Gurga Chiya, Trench E: Late Ubaid architecture and associated pottery scatter

Roaf 1984, fig. 20: 4-8, 12-13). A body sherd with an incised herringbone pattern also has parallels at the latter site (Moon and Roaf 1984, fig. 20: 7, 13). The majority of angle-neck jars are in heavy brown or greenish burnished fabrics (Fig. 12: 4-6). The base of an unusually large "chalice" (a shallow dish with an extended hollow conical base, "stands or braziers" in Rothman's terminology) was found in the main pot scatter of GC-E (Fig. 12: 8). Again, similar vessels are known from both Late Ubaid and LC1-3 contexts across north Iraq and north Syria (Moon and Roaf 1984, fig. 21: 16; Rothman 2002a, fig. 4: r, s; fig. 9: k; Kepinski 2011, pl. 3: 7-14, Pl. 15: 18; Tobler 1950, pl. 135: 270-71, pl. 146: 399401). A range of open forms (bowls or beakers) was also found. The most complete example, a medium-sized unpainted beaker (Fig. 12: 10; Fig. 13: right), can be compared to a plain Late 

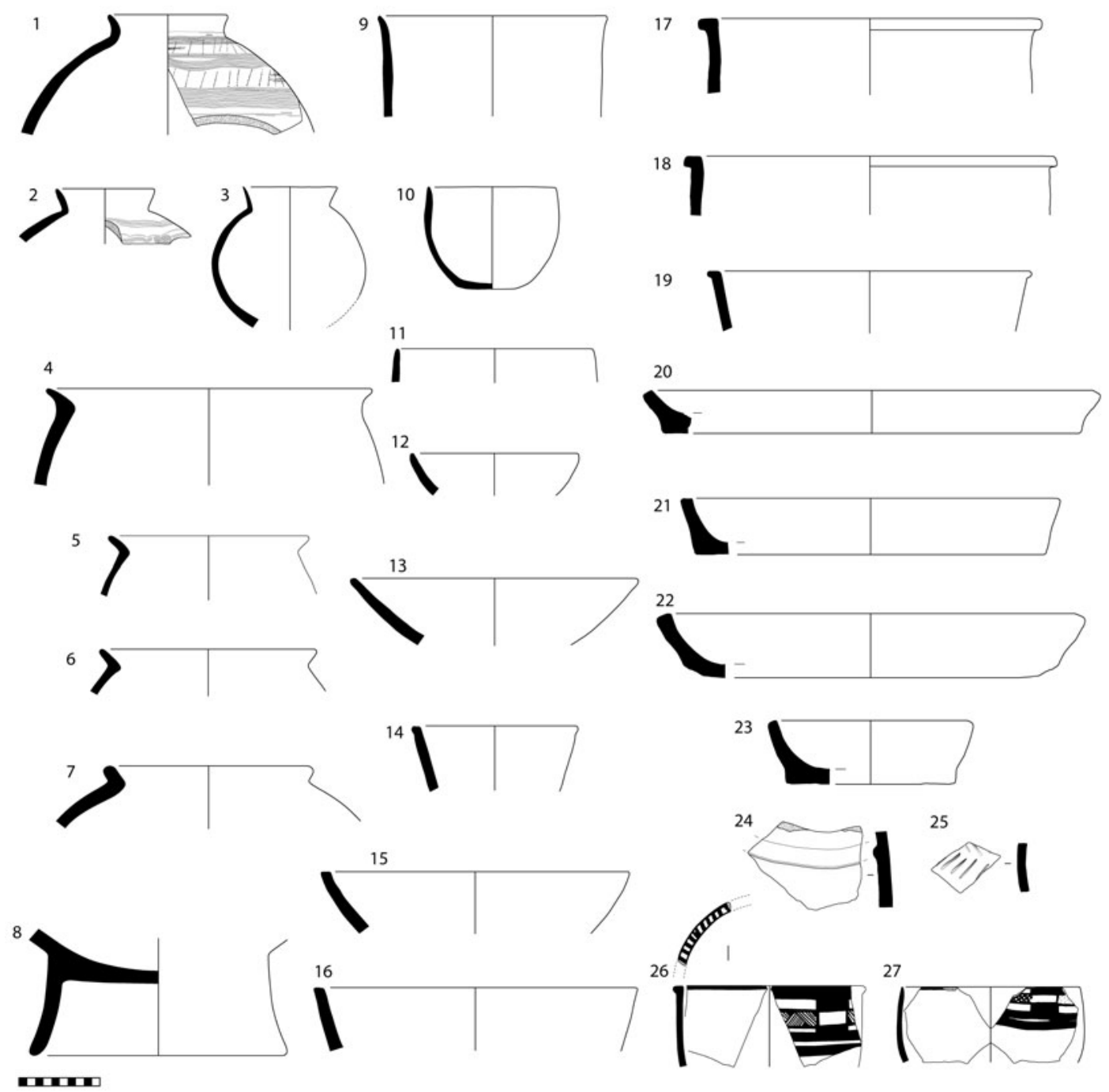

Fig. 12 Late Ubaid/Late Chalcolithic vessels from the pottery scatter in Trench E at Gurga Chiya. 1, 8, 12, 15, 20, 22: brown coarse chaff-tempered. 7, 9, 13, 14, 17, 18, 19, 21, 24: green coarse chaff tempered. 2, 3, 10, 25, 26, 27: green medium chaff-tempered. 4, 16: buff coarse chaff tempered with white inclusions. 5: brown burnished medium chaff tempered with quartz inclusions, lumpy surface. 6: green burnished with quartz inclusions, lumpy surface. 11, 23: brown burnished medium chaff tempered

Ubaid example from Gawra, "below XIII" (Tobler 1950, pl. 127: 171) and more precisely to plain Late Ubaid (i.e. Ubaid 4) beakers from Madhhur (Moon and Roaf 1984, fig. 16: 16-17, 20-21). Other more open forms (Fig. 12: 12-13) may relate to the Coba bowl tradition of flint-scraped vessels, considered hallmarks of standardisation and craft specialisation throughout the wider Near East in the pre-Uruk period (Marro 2012; Baldi 2012). Deep open vessels with flat toppedrims were also identified (Fig. 12: 14-16), while a high proportion exhibit horizontally extended rims (Fig. 12: 17-19), with both Late Ubaid and LC2-3 parallels at Madhhur and Grai Resh respectively (Moon and Roaf 1984, fig. 17: 6-7; Kepinski 2011, pl. 7: 1-2). Also common at Gurga Chiya were large open trays in a coarse vegetal tempered fabric ware (Fig. 12: 20-22). These do not appear to be widely characteristic of either the Late Ubaid or LC traditions in northern Mesopotamia. Similar, but considerably later, examples are known from Godin Tepe (Levels VI-VII), in the Kangavar Valley to the east (Rothman and Badler 2011, fig. 4: 52, Type Va). At Gurga Chiya these trays share their form and fabric with much earlier Late Neolithic 


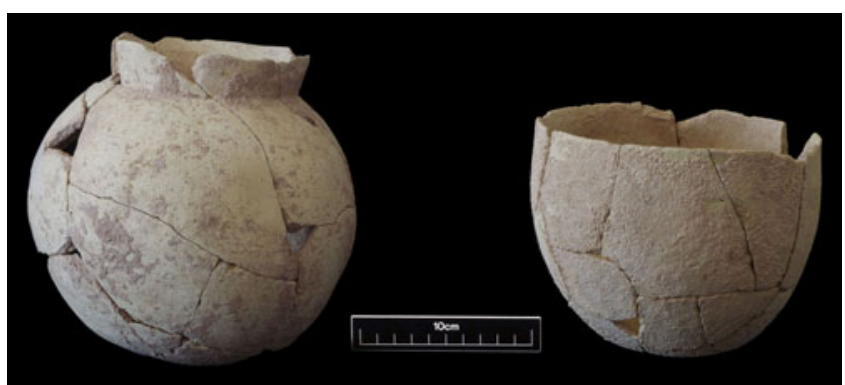

Fig. 13 Left: Reconstructed "angle-neck" jar. Right: beaker, both of green medium chaff-tempered ware, from Late Ubaid levels at Gurga Chiya (cf. Figs. 13: 3, 13: 10; photograph by G. Brereton)

(Halaf) pottery from the adjacent site of Tepe Marani (see below, and Fig. 19: 3-5, 9), perhaps pointing towards an element of long-term continuity in prehistoric traditions of cooking and cuisine along the western Zagros and adjacent foothill regions.

Painted pottery with simple geometric motifs was also recovered from the extended sherd deposit in Trench E, including two open-mouthed black-painted vessels, both with horizontal grids of filled and open rectangles (Fig. 12: 26-27). These are broadly comparable to decorated Late Ubaid sherds from Khanijdal East and Tepe Gawra XIII and "below XII" (i.e. Gawra XIIA; Wilkinson et al. 1996, fig. 12: 6, 9; Tobler 1950, pl. 127: 173, pl. 136: 278). Subject to further excavation and absolute dating, comparisons suggest a date close to the Late Ubaid-Late Chalcolithic transition (as described by Rothman 2002a; and at least partly overlapping with the Lower 3 segment of the Nineveh Deep Sounding sequence; Gut 1995: 92-95, 222-49). The relatively high percentage of painted pottery for this phase at Gurga Chiya (6.1 per cent by rim sherd count, 8.0 per cent by rim percentage) suggests that it is better described as Late Ubaid rather than LC1 or later (cf. Akkermans 1988a: 198, Table 31; Akkermans 1988b: 301, Table 50). This is supported by Late Ubaid parallels for the decorated vessels given above, both incised and painted. Furthermore, certain absences from the assemblage point towards a Late Ubaid attribution. For example Sprig Ware, characteristic of LC1 and LC2, is absent (cf. Rothman 2002a: Table 2). Double and multiple-mouthed jars, elsewhere characteristic of LC 1-3, are also currently missing, as are the "casseroles" typical of LC 2-3 (cf. Kepinski 2011, pl. 5: 1-5). "Double-rim jars" (cf. Rothman 2002a, fig. 6: d-f) and stamped rosette decoration - both associated with LC 2-are likewise absent.

\section{The Late Neolithic Period at Tepe Marani}

The presence of Late Neolithic settlement remains on the neighbouring mound of Tepe Marani, first noted during the pilot season of 2012, was confirmed by the excavation of two trenches in the central part of the site. Building foundations were located in TM-A and a series of midden deposits in the smaller exposure of TM-B (Fig. 3), yielding associated radiocarbon dates of the mid-late sixth millennium B.C. These were calibrated at 2-sigma to 5620-5480 cal. B.C. (Beta-368798, 6600 \pm 40 в.P.) for the architectural remains in TM-A, and 5320-5210 cal. в.C. and 5480-5230 cal. в.C. for the trash deposits of TM-B (Beta-368802, $6290 \pm 30$ B.P., and Beta-368801, $6370 \pm 40$ B.P.), placing the prehistoric settlement at Tepe Marani broadly within the Late Halaf or "Halaf-Ubaid transition phase" (cf. Campbell 2007).

The TM-B middens were formed by trash deposits sloping steeply downwards to an exposed depth of c. 1 metre (Fig. 14), reflecting multiple episodes of digging, dumping and burning, the latter indicated by thick lenses of ash containing fragments of charred bone and organic matter, as well as ground and chipped stone tools. The trash deposits rested on and were cut into a dense layer of stones and ceramic sherds, including a number of re-joinable pieces and pieces with mending holes. The majority of sherds were spread evenly across adjacent dumping levels, horizontally bedded to create a continuous surface of unclear function.

The upper stratum of TM-A, which lies close to the summit of Tepe Marani, was formed of calcic xeresol. This soil type, common throughout northern Iraq, has been described as "self mulching", 


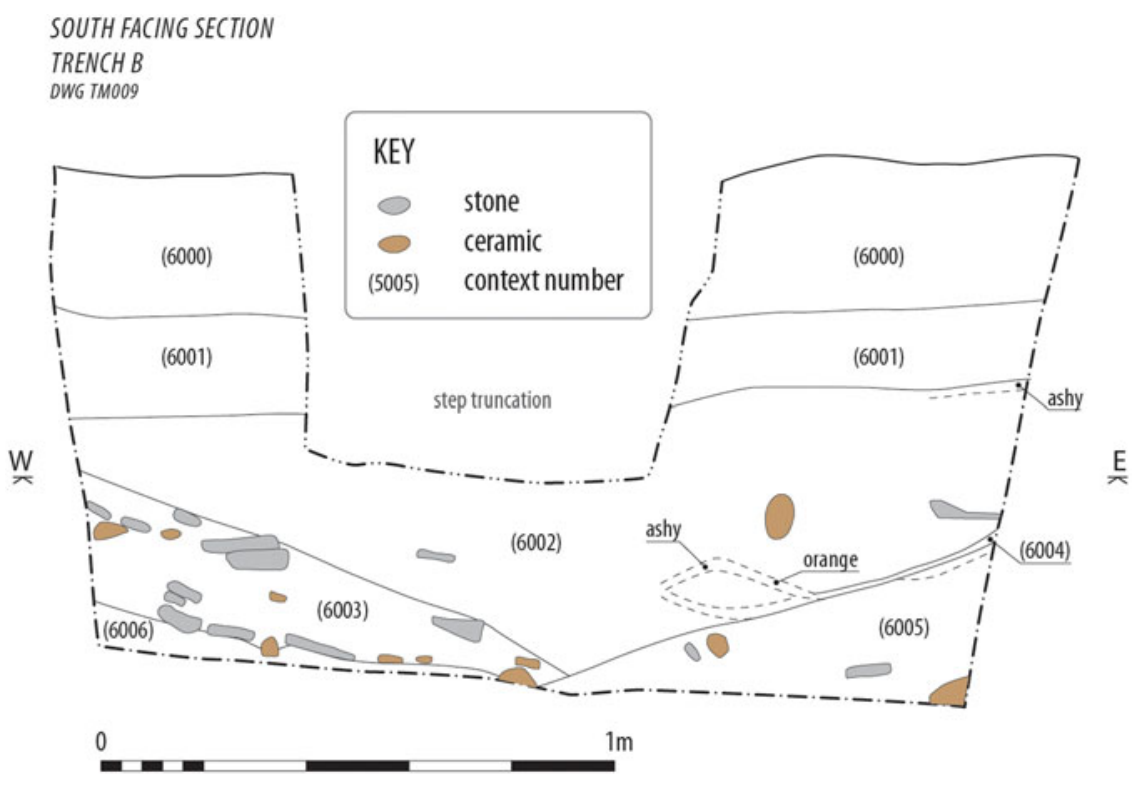

Fig. 14 Tepe Marani Trench B, northern section showing tip lines and overlapping trash deposits

such that features constructed of mud-brick or pisé are often transformed into a soil profile of natural appearance, leading to the disappearance of distinct strata, cut features, and structures. With sites over seven thousand years old, the upper habitation layers can become entirely homogenised by soil-forming processes, resulting in a matrix that contains only resistant artefacts such as pot sherds, worked stone, and large fragments of bone (Wilkinson and Tucker 1995: 5). This appears to be the case at Tepe Marani.

Among the finds and features observed "floating" in upper soil matrix of TM-A were concentrations of coarse pottery, bone, and chipped stone that may originally have been deposited within cut features, or on surfaces that are no longer visible. Notable small finds from these upper levels included a spindle whorl (Fig. 15: 1) and a steatite pendant with cross-hatched design (Fig. 15: 2), of a type widely documented throughout the Halaf culture area of northern Mesopotamia, and often interpreted as an early form of stamp seal for marking vessel closures (von Wickede 1990).

At a depth of $c .40$ centimetres, a single course of rough-cut stones (c. 20-30 centimetres in diameter) was encountered, curving away from the east face of the trench (Fig. 16). Running east, and level with the base of this foundation wall, was a compressed deposit of ceramic, stone, and organic remains embedded within an ashy soil matrix, and including numerous burnt pieces. It would appear to represent destruction and collapse from a curvilinear structure, the layout of which remains to be established.

Chipped stone artefacts recovered from Trenches A and B (Fig. 17) are made almost exclusively on chert of beige-grey or brownish red colour, with a range of green, pink, and yellow hues. Artefacts from obsidian account for only 1.5 per cent of the total number, substantially lower than at the majority of Halaf sites (Healey 2000: appendix 5). The assemblage is blade-oriented and broadly comparable to the Late Neolithic lithic industries of Tell Sabi Abyad (Copeland 1989), Yarim Tepe II (Merpert and Munchaev 1993) and Arpachiyah (Mallowan and Rose 1935). However, chert assemblages from other Halaf sites such as Umm Qseir (Maeda 1998) and also Banahilk, on the nearby Rawanduz Plain (Watson 1983: 572), were largely flake-based, indicating considerable variety in production and use of chipped stone across the wider region.

Only one core has so far been found on Tepe Marani (Fig. 17: 1), but some knapping activities clearly took place on-site as indicated by the high proportion of dorsal side cortex on 12 per cent of the assemblage. Blades were sometimes intentionally broken into shorter segments, and the vast 

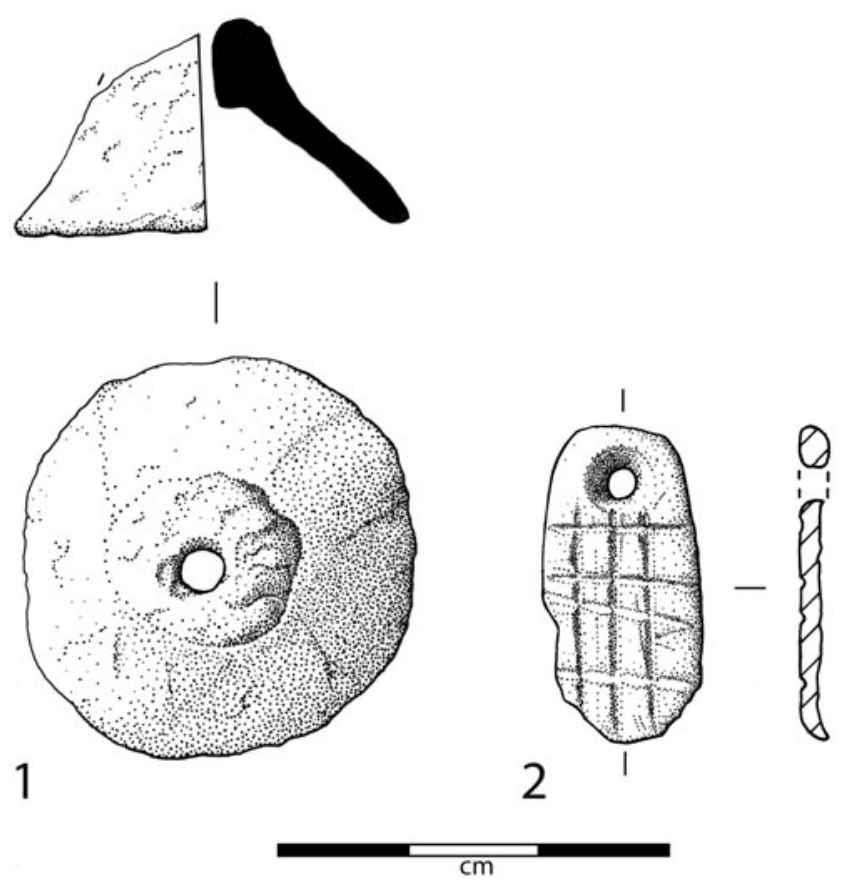

Fig. 15 1: Spindle whorl. 2: engraved stone pendant of Late Neolithic date from Tepe Marani, Trench A (drawn by N. B. Knudsen)

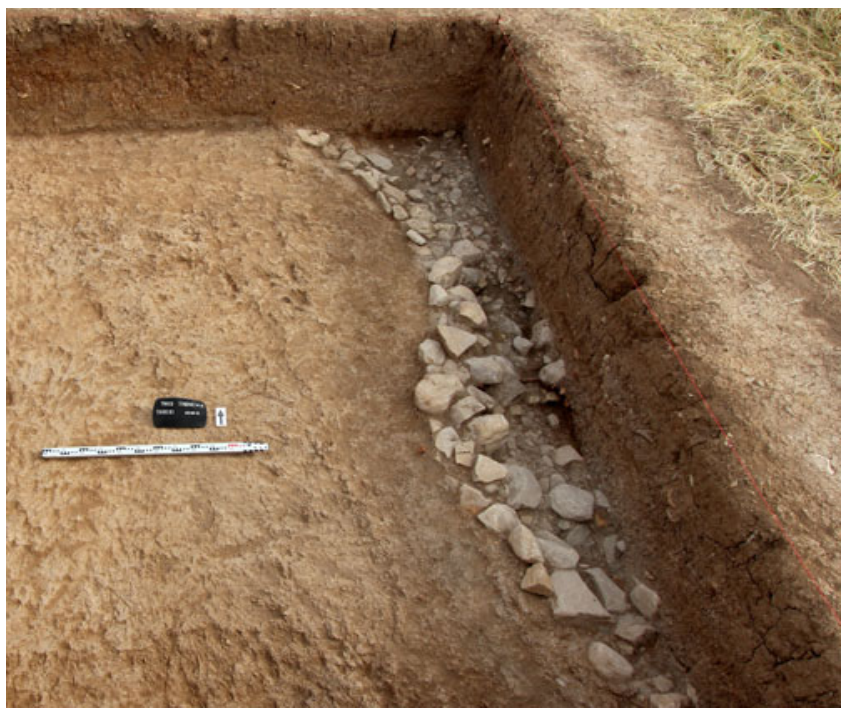

Fig. 16 Late Neolithic curvilinear structure in Trench A, Tepe Marani

majority show unidirectional scar patterning on the dorsal side. Other modified pieces include borers (Fig. 17: 5, 6), drills (Fig. 17: 7), burins (Fig. 17: 2-4), retouched blades and flakes, end-scrapers (Fig. 17: 8), and notched tools. Silica gloss was noted on a small number of blades and on one retouched blade. Among the more unusual lithic finds was an obsidian microlithic trapeze (Fig. 17: 16). Tepe Marani also produced a significant assemblage of ground stone artefacts, including beads and grinding tools, which await study. 

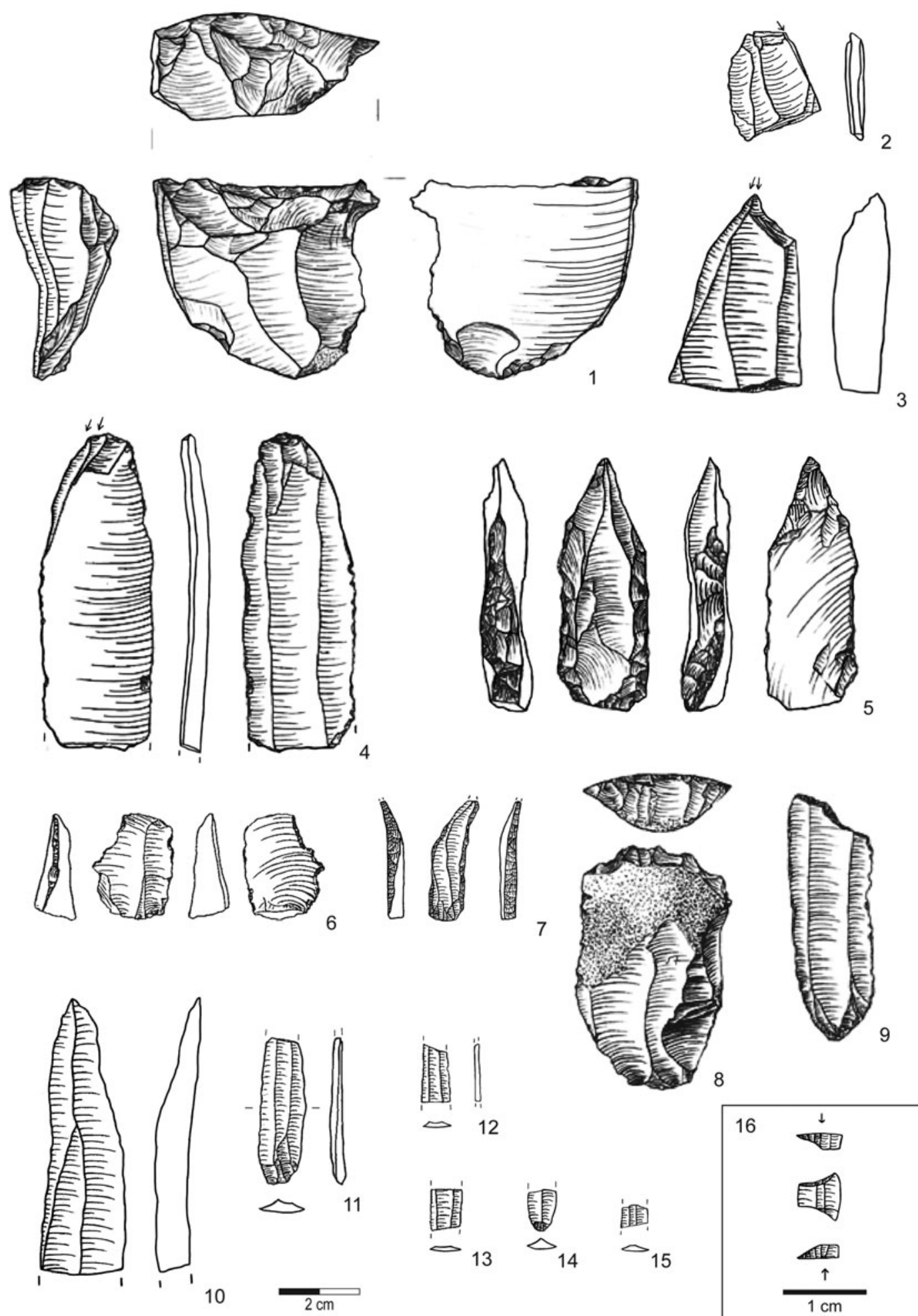

Fig. 17 Chipped stone artefacts of the Late Neolithic period from Tepe Marani (drawn by H. Sosnowska) 


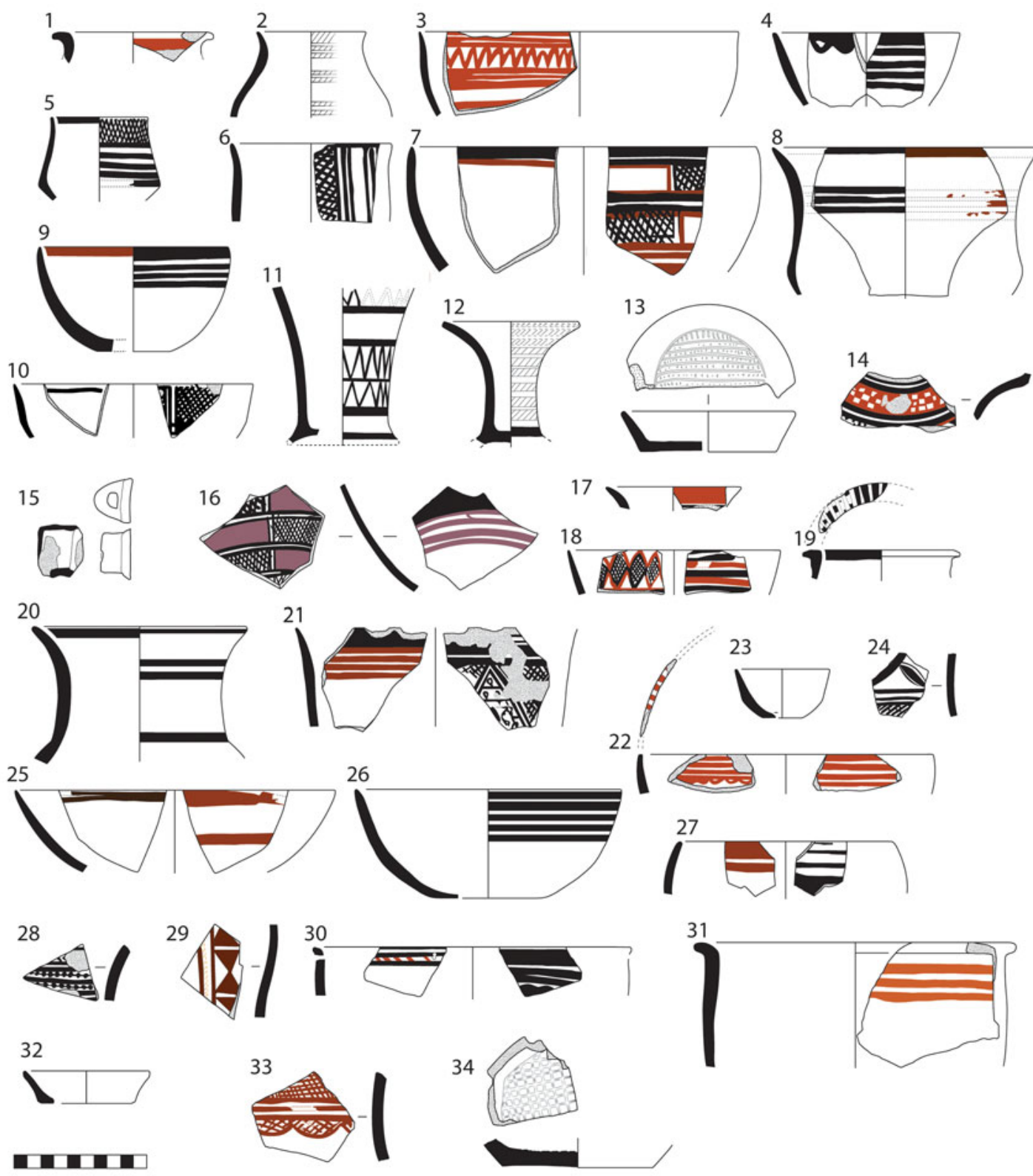

Fig. 18 Late Neolithic fine and medium wares from Tepe Marani. Illustrated paint colours are broadly indicative only, ranging from black to grey to brownish black (indicated in black), and from red to orange to redbrown to maroon (indicated in various shades of red). Faint traces of paint are indicated as hatched. 1-16: Fine ware with limy white inclusions and speckling. 17-30: Fine ware with no visible inclusions. 31-34: Medium ware with medium to fine chaff, limy white inclusions and speckling. Nos. 13 and 34 are incised

Further observations on the Late Neolithic ceramics from Tepe Marani

The two small trenches on Tepe Marani produced some 3880 sherds, many of which are highly decorated. The majority can be associated with the abandonment of the curvilinear structure in TM-A, and with the "pot pavement" of TM-B, forming a consistent Late Neolithic assemblage (although note the slightly later radiocarbon determinations for the latter context).

Pottery from Tepe Marani is entirely handmade, either by moulding in a basket or slab construction. Coarse and fine wares were readily distinguished, with ornamentation confined almost exclusively to the latter. The majority of vessels are fine ware bowls (Fig. 18: 1-30), 

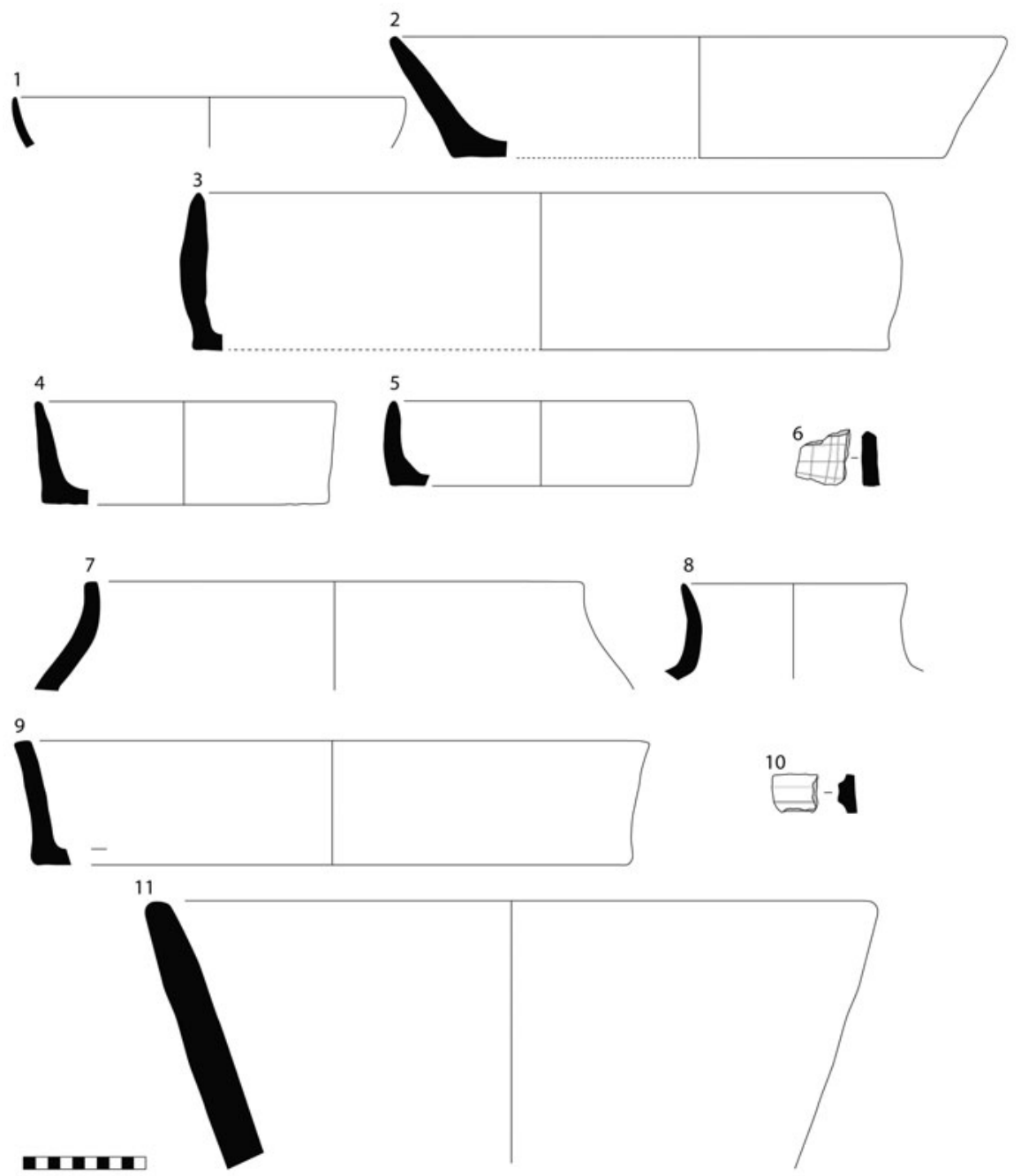

Fig. 19 Late Neolithic coarse wares from Tepe Marani. 1-6: brown coarse ware with coarse chaff temper and variable quantity of white inclusions. 7-11: buff coarse ware with coarse chaff temper and frequent white inclusions

followed numerically by thicker coarse ware bowls (Fig. 19: 11). Fragments of large storage jars (Fig. 19: 7-8) and shallow basins (Fig. 20: 2-5, 9) were also common. Certain vessel types may be distinctive to the Shahrizor Plain: notably a range of painted fine, medium and coarse ware dishes with deep incisions forming a grid across the interior base (Fig. 18: 13, 34; Fig. 19: 6; Fig. 20: top). Incised-base dishes of the same distinctive type were found at nearby Tell Begum, north of the Darband-i Khan Lake (Hijjara 1997, pl. 87:1).

Painted decoration on fine wares at Tepe Marani includes monochrome, bichrome, and polychrome designs (Fig. 18). The most common combination is black and red, although redorange, maroon, purple and white pigment was also used. Geometric designs include crosshatched and checked patterns common to Halaf assemblages at chronologically earlier sites, such as Arpachiyah in Nineveh Province (Mallowan and Rose 1935) and contemporaneous levels at Domuztepe in southern Turkey (Campbell et al. 1999; Spataro and Fletcher 2010). Closer to hand, comparisons can be drawn with Halaf pottery assemblages from Tell Hassan (in the Jebel Hamrin region; Fiorina and Bulgarelli 1985), from Kudish Saghir (near Kirkuk; Starr 1937-39), Banahilk (in the Rawanduz Plain), and above all from nearby Tell Begum (Nieuwenhuyse et al. 


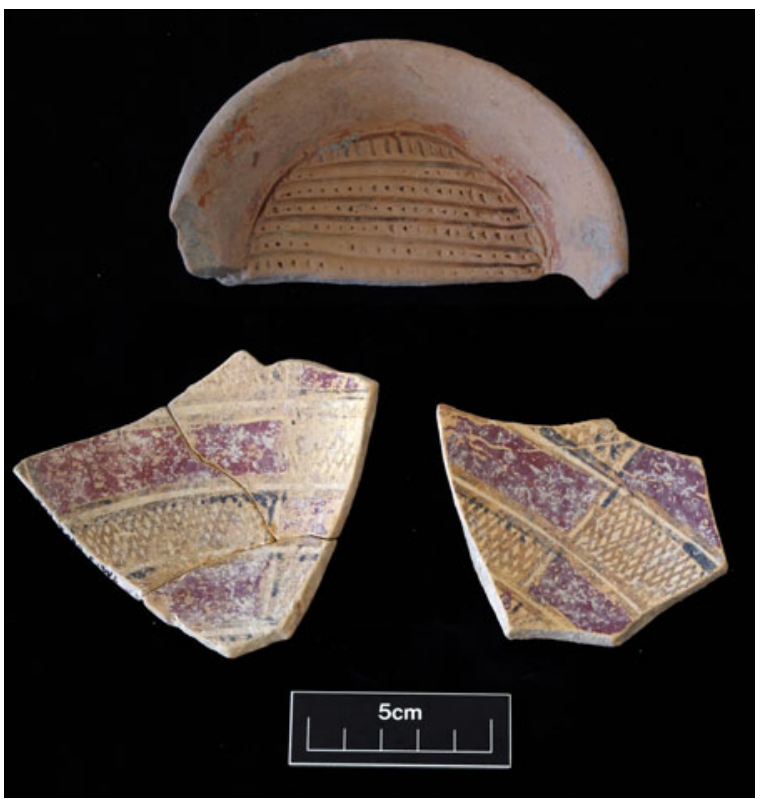

Fig. 20 Examples of base-incised and polychrome painted wares from Tepe Marani (photograph by G. Brereton)

2016). However, certain decorative elements typical of Halaf pottery elsewhere-including figural motifs depicting horned animals and flora-have not yet been documented at Tepe Marani.

Overall the Tepe Marani ceramic assemblage exhibits striking variation in vessel form (even within particular classes of vessel, for which see Chart 1), and also in the execution of decorative designs. Such pronounced variation at the level of individual vessels suggests that precise replication of finished ceramic products was consciously avoided by potters, even as general principles of manufacture and ornamentation became widely disseminated between small-scale communities across the northern part of the Fertile Crescent, including Iraqi Kurdistan. Avoidance of exact copying within a shared technological milieu is typical of Late Neolithic pottery assemblages across this much wider region - most notably in fine, ornamented wares - and can be regarded as a defining feature of the Halaf cultural expansion, giving way gradually to more standardised modes of ceramic production and reduced ornamentation during the Ubaid and Uruk periods (cf. Wengrow 1998; 2001). These broader cultural trends are clearly replicated within the late prehistoric assemblages at Tepe Marani and Gurga Chiya, and more widely within the Shahrizor.

\section{Environmental archaeology (see also Appendices 1 and 2)}

Botanical assemblages: Tepe Marani. From the initial season at Tepe Marani, fourteen flotation samples were studied from approximately 280 litres of sediment. These produced 695 seeds and seed fragments. The vast majority come from midden deposits in Trench B. They appear consistent with the disposal of hearth cleanings, which incorporated waste from cereal de-husking and cooking accidents. The Tepe Marani assemblage is dominated by pulses (57.7 per cent) followed by cereals ( 23.2 per cent), with 2.6 per cent flax and 15.7 per cent various wild seeds probable attributable to arable weeds (Chart 2).

Despite the large numbers of pulses, wheat has the highest ubiquity, being present in 60 per cent of samples. Of note are the single finds of a pear (Pyrus sp.) and a fig seed (Ficus sp.). Wheat is predominantly emmer (Triticum cf. dicoccum), represented by 10 grains and 50 glume-bases. A few grains of probable two-grained einkorn (Triticum cf.) are present. Barley included symmetrical and asymmetrical grains, suggesting a six-row form, primarily hulled (Hordeum vulgare L.). The pronounced dominance of wheat over barley is characteristic of other Late Neolithic 

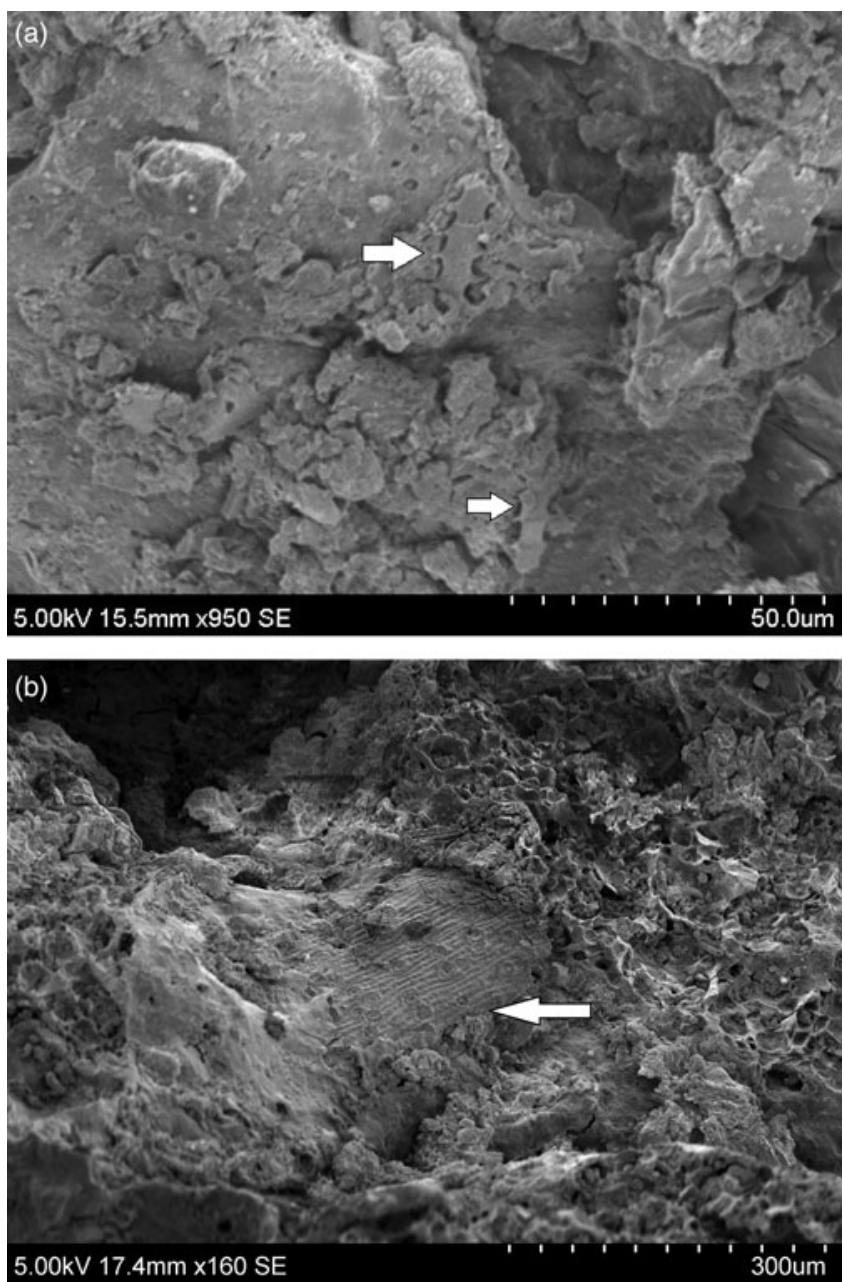

Fig. 21 SEM images: a. Late Neolithic fragments of processed grain from Trench B at Tepe Marani; b. Late Bronze Age charred fragments of food from Trench C at Gurga Chiya

archaeobotanical assemblages including Ras Shamra IV, Domuztepe, Umm Qseir, Tell Aqab (Kansa et al. 2009; McCorriston 1992; Van Zeist 1984). Large quantities of lentils with fewer bitter vetch are found at these other sites.

Of particular note is the high level of flax (Linum ussitatissimum) at Tepe Marani. Although very few seeds have been noted at the sites of Ras Shamra and Domuztepe this is in relation to 1000s of cereal remains, while the appearance of 2.6 per cent flax in the present, smaller assemblage is significant, given that an oily seed of this type has strong preservation bias against it. Flax was likely a multipurpose crop, having been grown as an edible oilseed (high in omega- 3 fatty acids) as well as for its stem's fibres. While genetic data indicates that oilseed or unspecialised varieties are primitive, with specially adapted high fibre-producing varieties being a later development, it is clear from textile finds in the Pre-Pottery Neolithic (e.g. at Çatalhöyük, in central Turkey) that textile production was established quite early. Given the additional presence of spindle whorls (Fig. 15: 1), it seems likely that textiles were among the Late Neolithic craft products at Tepe Marani.

Botanical assemblages: Gurga Chiya. The quantity of archaeobotanical information from Gurga Chiya is so far smaller than at Tepe Marani. This can be partly attributed to the shallowness of the initial trench samples in 2013. The Late/Terminal Ubaid phase is represented by a single assemblage, from Trench E, which confirms the presence of wheat and lentil. The fourth 


\section{Proportions of General Types:}

From rim counts of contexts (5003), (5012), (6002), (6003)

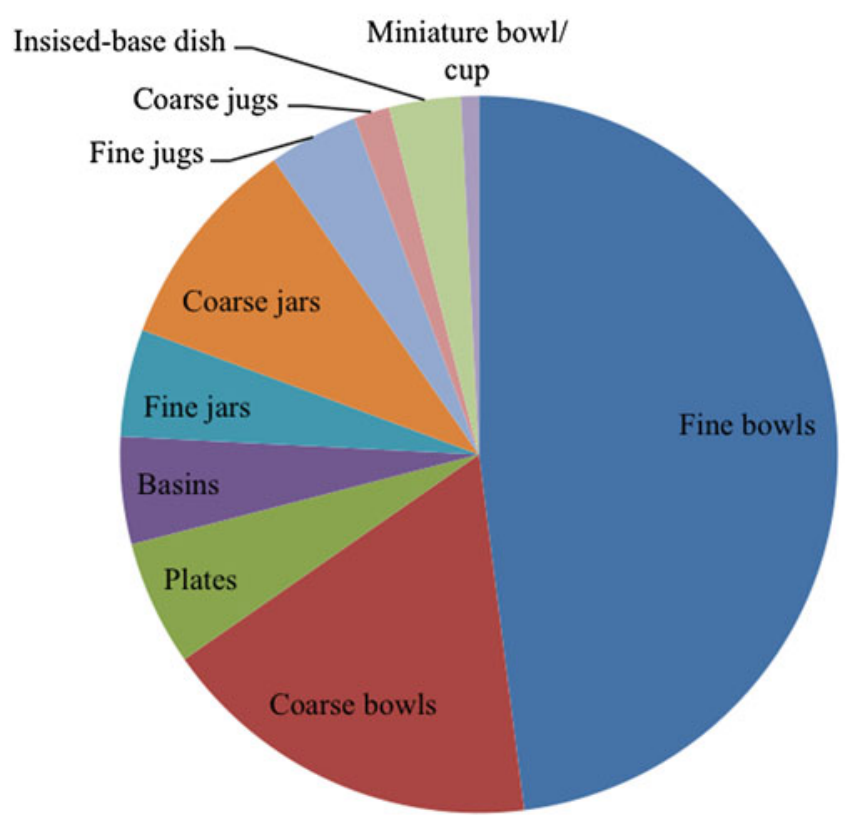

Chart 1 Proportions of main Late Neolithic vessel types at Tepe Marani (by H. Himmelman)
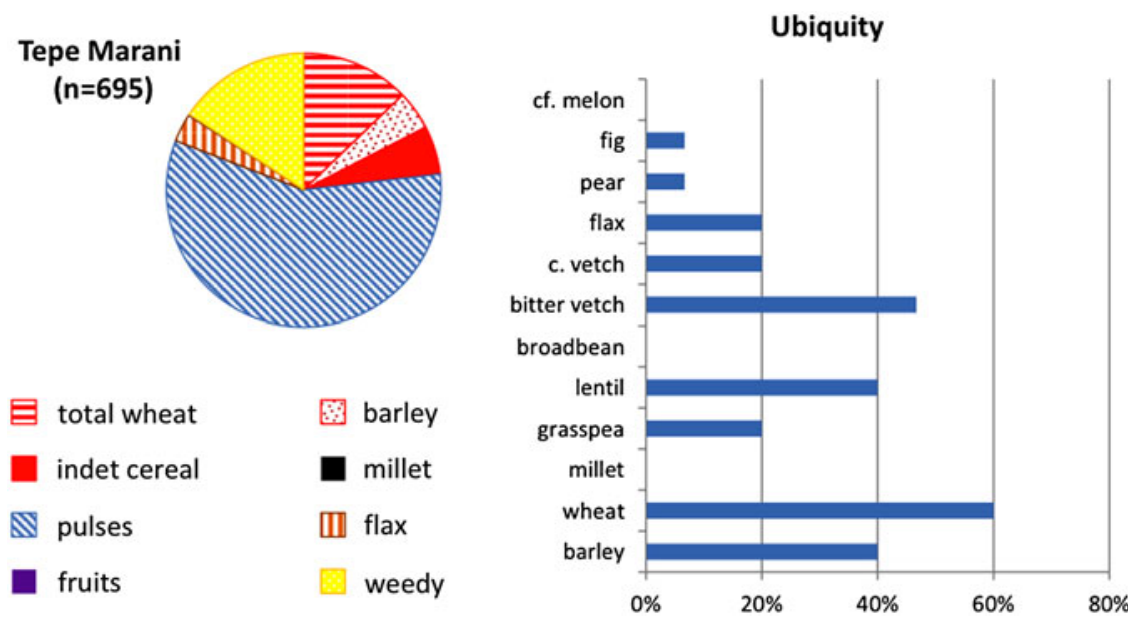

Chart 2 Proportions of plant categories in the overall Tepe Marani assemblage, and the ubiquity ( $\%$ of sample in which present) for selected taxa (bar chart to right; by D. Fuller)

millennium B.C. is represented by samples from Trench F, notably from within the soil matrix of a large accumulation of Middle Uruk pottery. Its contents include crops, a small amount of wheat chaff, and an assortment of wild seeds most probably deriving from weeds ( 28 per cent). This sample is dominated by lentils (Lens culinaris) (30 per cent) but includes barley (Hordeum vulgare L.) (6.5 per cent) and wheat, including probable one-grained einkorn (Triticum monococcum). A single specimen of broad bean (cf. Vicia faba) was found. Of interest are a small number of possible mustard seeds (BrassicalSinapsis sp.), which warrant further examination.

Late Bronze Age agriculture at Gurga Chiya is represented by an assemblage from Trench C, which represents the charred contents of an oven dated to the fourteenth or early thirteenth 
centuries cal. B.C. (see above). About half the sample consists of various seeds of wild/weedy taxa, and crops (wheat and barley) account for around 28 per cent, split evenly between barley and wheat. The barley may be mainly two-row hulled, while the wheat where identifiable is emmer. Pulses (17.5 per cent) are dominated by lentil and bitter vetch, with a single specimen of probable pea (cf. Pisum sativum).

Of particular interest is the presence of a well-preserved grain of millet (Panicum miliaceum) in the thirteenth/fourteenth century B.c. sample, and two seeds most probably of melon (cf. Cucumis melo). Melon may have been established in the Bronze Age Indus Valley, and still earlier in predynastic Egypt (Fahmy et al. 2011); but finds in Mesopotamia have been rare (Zohary et al. 2012). Millet is of particular interest as this species originated in China and its early dispersal westwards into Europe and the Near East has been controversial. Despite claims for Neolithic finds in Europe, critical reviews suggest an initial arrival after 3000 B.C., with reliable direct AMS dates only from c. 1500 B.c. (e.g. Boivin et al. 2012; Motuzaite-Matuzeviciute et al. 2013; Valamoti 2013). In Mesopotamia, finds at Nimrud may be early Iron Age, while those from Haftavan in northwest Iran date between 1700-1300 B.C. (Miller 1991; Zohary et al. 2012). The isolated find from Gurga Chiya may therefore relate to the initial spread of this summer season crop into the Mesopotamian lowlands.

Charred food remains Twenty-five flotation samples from Tepe Marani and eleven from Gurga Chiya were scanned for charred food remains represented by amorphous charred organic lumps. The occurrence of this type of material is very high, with food fragments recovered from more than 60 per cent of the flotation samples at both sites. These remains were initially examined under low-powered binocular microscope ( 0.8 to 4.0 magnification) to identify preliminary plant cell structures, which were then further analysed using Scanning Electronic Microscopy. Epidermal fragments, most likely from wheat (Triticum cf.), were identified within Late Neolithic (5480-5230 cal. B.C.) fragments of processed grain from Trench B at Tepe Marani (Fig. 21: a). Additionally, Late Bronze Age (1390-1120 cal. B.C.) charred fragments of food were recovered from Trench C at Gurga Chiya (Fig. 21: b). Very clear epidermal cell structures of wheat, Triticum cf. and barley, Hordeum vulgare (ind. var) have been identified within the Gurga Chiya food remains, suggesting the mixing of different cereal ingredients in the preparation of Bronze Age meals.

A note on animal bone assemblages (by Elizabeth Farebrother). The first series of excavations at Gurga Ciya and Tepe Marani yielded a significant assemblage of animal bones fragments, which are currently undergoing zoo-archaeological analysis. It is already clear that cattle, caprines (sheep and goat) and pig are the most commonly represented fauna at both sites. More precise identifications of species and the proportion of wild to domestic taxa will be clarified in a future report. Evidence of carnivore gnawing and burning is visible within both assemblages, and butchery marks were observed on the faunal remains from Gurga Chiya. Molluscs and microfaunal remains were recovered from both sites. Adult and sub-adult animal mandibles - mainly from cattle, caprines, and pig - were recovered from Gurga Chiya. At present much of the dental material from Tepe Marani is represented by individual teeth. Dental ageing studies, plus epiphyseal fusion analysis, are planned in order to investigate changing methods of animal management in the later prehistory of the Shahrizor.

\section{Summary, preliminary interpretations, and conclusion}

The main achievement of the excavations at Tepe Marani and Gurga Chiya so far has been to document prehistoric human settlement of the southern Shahrizor, spanning a period of more than two millennia, between $c .5600$ and 3300 B.c. The results demonstrate beyond doubt that the "hilly flanks" of the Zagros-long famous for their Palaeolithic, Epipalaeolithic and Early Neolithic sites - were also fully integrated into later prehistoric developments affecting the wider Middle East.

Of particular interest is the discovery of a Middle Uruk assemblage in the Late Chalcolithic 3-4 levels at Gurga Chiya. While not associated with preserved architecture, the presence of a representative suite of southern Mesopotamian-style pottery at this location, together with associated radiocarbon dates, adds to an emerging picture of cross-regional interaction along the 
northern tributaries of the Tigris during the fourth millennium B.c. This emerging picture has implications for any wider understanding of the "Uruk expansion", arguably the earliest largescale commercial and colonial expansion in world history, with its epicentre on the southern Mesopotamian alluvium (Algaze 2008; Wengrow 2010: 66-87).

In his original analysis of that process, Guillermo Algaze (1993: 63-72) envisaged an intensification of cultural contact and exchange between urban centres of the Mesopotamian floodplain and riverine populations inhabiting the main routes between the Tigris piedmont and the central Zagros. Such a process would mirror developments far to the west along the MiddleUpper Euphrates and the Taurus foothills, where the Uruk expansion is documented through detailed archaeological surveys and excavations. Algaze suggested that the penetration of Urukrelated assemblages and manufactured products into these distant areas reflects a predatory expansion of lowland Mesopotamian commercial interests, providing densely populated cities on the alluvium with access to upland resources such as metals, timber, and minerals.

The application of Algaze's model to the lands east of the Tigris was initially based on slim but suggestive evidence from sites such as Qalinj Agha (in the suburbs of Erbil), Nuzi (Yorghan Tepe), and indeed Bakr Awa, where small quantities of Uruk-style pottery and occasionally architecture were documented in brief preliminary reports. Subsequent excavations at Bakr Awa, discussed earlier, substantiate his thesis, as does new fieldwork at the much smaller (c. 1 hectare) site of Kani Shaie, overlooking a key overland pass through the Bazian Mountains and the Shahrizor Plain (Renette, forthcoming). As at Gurga Chiya, the Uruk assemblage at Kani Shaie has been dated to the LC 4 phase, around the middle of the fourth millennium B.c. In combination, the new evidence from these two sites demonstrates an expansion of southern Mesopotamian contacts along the principal left bank tributaries of the Tigris, perhaps some centuries prior to the consolidation of (Late) Uruk contacts along the Khorasan Road to the south, as attested at Godin Tepe VI:1 (for which, see Gopnick and Rothman eds. 2011).

The establishment and intensification of contacts between lowland Mesopotamia and the central Zagros region in the fourth millennium B.C. was a complex process, reflecting - not just long-range flows of people and resources - but also cultural choices taking place at a local scale, including the exchange of specialised knowledge concerning seasonally variable routes and resources (Rothman 2013; Wilkinson 2014). A diversity of responses to the possibilities of long-distance trade is already evident in the western Zagros and adjoining lowlands in the preceding (Ubaid) period. Among earlier studies, petrographic analysis of ceramics by Elizabeth Henrickson (1989) was especially significant in revealing divergent patterns of cultural interaction between villages of the Ubaid tradition and the central Zagros highlands.

Settlements in the Jebel Hamrin region, such as those at Tell Abada (Jasim 1985) and Tell Madhhur (Roaf 1989) - both with close ceramic parallels in the lower levels at Gurga Chiya - were already linked through exchange to the Mahidasht and Kangavar Valleys (segments of the Khorasan Road) in the fifth millennium B.C. But the links are evident primarily in the mixing of local ceramic traditions, rather than the flow of metals and minerals obtained from further afield on the Iranian Plateau (Henrickson 1989). The scarcity of such long-range imports at both Tell Abada and Tell Madhhur is intriguing, especially when contrasted with the emergent situation at Tepe Gawra (levels XIII-XIIA), on the Tigris piedmont to the north (Rothman 2002b). There, in the Late Ubaid period, interaction with the peoples of the Zagros had already produced a westward flow of materials such as lapis lazuli, copper, and obsidian, later accompanied by gold, carnelian, and no doubt also perishable goods such as upland fauna, flora, and fine timber (Rothman 2001: 379).

Many of these imported materials would subsequently become key markers of value for lowland urban societies (Wengrow 2010). However, their status as "luxuries" and "valuables" appears not to have been self-evident, and was most likely contested on a local scale, especially during the initial expansion of highland-lowland contacts in the sixth and fifth millennia B.C. In this respect the Shahrizor Plain can be seen to lie midway between two alternative paths of interaction between the Ubaid lowlands and the neighbouring Zagros - one route passing to the north, along the southern shores of Lake Urmia, and the other to the south, through the Mahidasht-which in turn seem to have been characterised by different sets of values and priorities. 
On a wider scale the fifth millennium B.C. is characterised by the transfer of Ubaid material cultureincluding a characteristic range of craft products and house forms - over a truly enormous area, reaching at its maximum extent from the Arabian Gulf to the eastern corner of the Mediterranean, but with no obvious centre of gravity (Wengrow 2010: 54-65). Understanding this process on a macro-regional scale has proved extremely difficult, and recent interpretation focuses increasingly on the diversity of local interactions - terrestrial and maritime - that underpin the apparent homogeneity of Ubaid material culture (see Carter and Philip eds. 2010). Further investigation of the Ubaid levels at Gurga Chiya will add a significant dimension to our understanding of these localised patterns of interaction as played out on the eastern frontier of the Mesopotamian world, including their place in the wider Ubaid interaction sphere and their subsequent transformation in the Uruk period.

The Late Neolithic habitation at Tepe Marani, adjacent to Gurga Chiya, spans the mid-late sixth millennium B.C., and so far exhibits a variety of features consistent with Halaf-period sites in northern Mesopotamia, the Diyala Plain, and the Jebel Hamrin. They include a rich and diverse assemblage of hand-made and painted pottery, the use of stamp seals as personal amulets (and possibly also for the marking of sealed goods), and evidence for the processing of flax into yarn. Less typical at this point is an apparently low frequency of obsidian in the lithic assemblage, and the absence of figural ornamentation from pottery. Further comparison of botanical and faunal assemblages from Tepe Marani and Gurga Chiya has the potential to shed light on long-debated issues of cultural change in the later prehistory of the region such as the transition from flax to wool as a primary textile material (McCorriston 1997), the beginnings of animal traction and the origin of dietary changes such as the inception of fermented cereal (bread and beer) and processed dairy products (cf. Sherratt 1997; Evershed et al. 2008).

Such wider questions are best addressed in view of more local issues of interpretation. What, for example, prompted the relocation of human settlement from Tepe Marani to the nearby site of Gurga Chiya, sometime towards the close of the sixth millennium B.c.? To what extent can continuity and change be detected in the material culture, subsistence economies, and social organization of the people who inhabited these two sites? Why the long hiatus between Uruk and Late Bronze Age levels at Gurga Chiya, by contrast with the similarly proportioned site of Kanie Shaie to the west, where substantial third millennium occupation is evident? How do these localised shifts in habitation reflect the distinct ecology of the Shahrizor, with its atypical levels of precipitation? To what extent were they enabled or constrained by wider patterns of interaction between the Mesopotamian lowlands and the highlands of western Iran, as these shifted and expanded over a period of millennia? Answering such questions will require further fieldwork, and continued protection of the Shahrizor's rich archaeological landscape from the effects of intensive agriculture and mineral prospection.

Appendix 1: Archaeobotanical data from Tepe Marani. Counts represent number of identifiable specimens. Each sample was approximately 20 L original sediment volume.

\begin{tabular}{lcccrrr}
\hline Context & 5001 & 5003 & 5005 & 5012 & 6002 & 6003 \\
\hline \# of samples & 1 & 2 & 1 & 2 & 3 & 4 \\
CEREALS Hordeum vulgare & - & 1 & - & 21 & 9 & 1 \\
Triticum cf. 2gr. Einkorn & - & - & - & 3 & - & - \\
Triticum dicoccum & - & - & - & 4 & 6 & - \\
Triticum cf. indet & 1 & - & - & 19 & 10 & - \\
Triticum cf. glume bases & - & 3 & - & 17 & 22 & - \\
Cereal frags. & - & 1 & - & - & 4 & - \\
PULSES & - & - & - & - & 173 & 1 \\
Lathyrus sativus & - & - & - & - & Continued \\
Lens culinaris & & & & & &
\end{tabular}


Appendix 1: (Continued)

\begin{tabular}{|c|c|c|c|c|c|c|}
\hline Context & 5001 & 5003 & 5005 & 5012 & 6002 & 6003 \\
\hline Vicia ervilia & - & - & - & 1 & 34 & - \\
\hline Vicia sativa & - & - & - & - & 4 & - \\
\hline Viciae frag & - & - & - & - & 21 & - \\
\hline Large legume frag & - & 3 & - & - & 159 & - \\
\hline \multicolumn{7}{|l|}{ OTHER CROPS } \\
\hline Linum usitatissimum & 1 & - & 3 & - & 19 & - \\
\hline \multicolumn{7}{|l|}{ Wild/ Weed } \\
\hline Adonis sp. & - & - & - & - & 1 & - \\
\hline Aegilops sp. & - & - & - & - & 1 & - \\
\hline Centaurea sp. & - & - & - & - & 7 & - \\
\hline Bolboschoenus glaucus & - & - & 1 & - & - & - \\
\hline Fabaceae, small & - & - & - & - & 3 & - \\
\hline Galium cf. tricornutum & 7 & - & - & 1 & - & - \\
\hline Plantago/Crucianella & - & - & 1 & - & - & - \\
\hline Glaucium sp. & - & - & 1 & - & 1 & 1 \\
\hline Liliaceae type & - & - & - & - & 37 & - \\
\hline Liliaceae: cf. Ornithogalum & - & - & - & - & 2 & - \\
\hline cf. Brassicaceae & - & - & - & - & 1 & 1 \\
\hline cf. Caryophyllaceae & - & - & 1 & - & - & - \\
\hline cf. Suaeda & - & - & - & - & 9 & - \\
\hline Phragmites sp. & - & - & - & 1 & - & - \\
\hline Poaceae, small & - & - & - & - & 1 & - \\
\hline Pyrus sp. & - & - & - & - & 1 & - \\
\hline Indet small seeds & - & - & - & - & 7 & 17 \\
\hline Indet fragments & - & 11 & 29 & 50 & 86 & 22 \\
\hline Parenchyma/ food residue & - & - & - & 4 & 14 & 22 \\
\hline Sclerotia & - & 1 & 5 & - & - & - \\
\hline
\end{tabular}

Appendix 2: Archaeobotanical data from Gurga Chiya. Counts represent number of identifiable specimens. Each sample was approximately 20 L original sediment volume.

\begin{tabular}{|c|c|c|c|c|}
\hline Trench & $E$ & $F$ & C & $D$ \\
\hline Context & 1515 & 304 & 210 & $1004 / 1005$ \\
\hline \# of samples & 1 & 4 & 3 & \\
\hline \multicolumn{5}{|l|}{ CEREALS } \\
\hline Hordeum vulgare & - & 9 & 10 & \\
\hline Triticum dicoccum & - & - & 2 & \\
\hline Triticum cf. indet & 1 & 2 & 5 & \\
\hline Triticum cf. glume bases & & 3 & 5 & \\
\hline Cereal frags. & - & - & 13 & \\
\hline Panicum miliaceum & - & - & 1 & \\
\hline \multicolumn{5}{|l|}{ PULSES } \\
\hline Lathyrus sativus & - & 1 & - & \\
\hline Lens culinaris & 1 & 41 & 7 & \\
\hline Pisum sativum & - & - & 1 & \\
\hline Vicia faba & - & 1 & - & \\
\hline Vicia ervilia & - & - & 4 & \\
\hline Vicia sp. & 2 & - & 7 & \\
\hline Large legume frag & - & 1 & - & 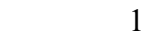 \\
\hline \multicolumn{5}{|l|}{ OTHER CROPS } \\
\hline Cucumis cf. melo & - & - & 2 & \\
\hline Brassica/Sinapsis & - & 8 & & \\
\hline
\end{tabular}


Appendix 2: (Continued)

\begin{tabular}{|c|c|c|c|c|}
\hline Trench & $E$ & $F$ & $C$ & $D$ \\
\hline \multicolumn{5}{|l|}{ Wild/ Weed } \\
\hline nutshell & - & - & 1 & \\
\hline Apiaceae type & - & - & 1 & \\
\hline Bromus sp. & - & 3 & 11 & \\
\hline Centaurea sp. & - & - & 1 & \\
\hline Cyperaceae: Eleocharis type & - & - & 1 & \\
\hline Fabaceae, small & - & - & - & \\
\hline cf. Eremopyron & - & 1 & - & \\
\hline Galium cf. tricornutum & - & - & 2 & \\
\hline Lolium/Hordeum wild & - & 1 & 1 & \\
\hline cf. Brassicaceae & - & - & 2 & \\
\hline indet small seeds & - & 1 & 7 & \\
\hline Polygonaceae & - & - & 1 & \\
\hline cf. Phragmites sp. & - & - & 17 & \\
\hline Poaceae, small Grass indet & - & 1 & 6 & \\
\hline Parenchyma/food residue & 4 & 3 & - & \\
\hline Indet fragments & 9 & 5 & 65 & \\
\hline
\end{tabular}

\section{Bibliography}

Abu Jayyab, K. 2012. A ceramic chronology from Tell Hamoukar's southern extension. Pp. 87-123 in C. Marro (ed.), After the Ubaid: Interpreting Change from the Caucasus to Mesopotamia at the Dawn of Urban Civilization (4500-3500 BC). Paris: De Boccard.

Akkermans, P.M.M.G. 1988a. Chapter 7: The Period IV Pottery. Pp. 181-285 in M. van Loon (ed.), Hammam Et-Turkman I. Leiden: Nederlands Instituut Voor Nabije Oosten.

- 1988b. Chapter 8: The Period V Pottery. Pp. 287-349 in M. van Loon (ed.) Hammam Et-Turkman I. Leiden: Nederlands Instituut Voor Nabije Oosten.

Algaze, G. 1993. The Uruk Expansion: the Dynamics of Expansion of Early Mesopotamian Civilisation. Chicago and London: University of Chicago Press.

- 2008. Ancient Mesopotamia at the Dawn of Civilization: The Evolution of an Urban Landscape. Chicago: University of Chicago Press.

Altaweel, M., A. Marsh, S. Mühl, O. Nieuwenhuyse, K. Radner, K. Rasheed and S.A. Saber. 2012. New investigations in the environment, history, and archaeology of the Iraqi hilly flanks: Shahrizor Survey Project 2009-2011. Iraq 74: 1-35.

Asouti, E. and C. Kubukcu. 2014. Holocene semi-arid oak woodlands in the Irano-Anatolian region of Southwest Asia: natural or anthropogenic? Quaternary International 90: 158-82.

Baird, D. 2012. The Late Epipalaeolithic, Neolthic, and Chalcolithic of the Anatolian Plateau, 13,000-4000 BC. Pp. 431-65 in D.T. Potts (ed.), A Companion to the Archaeology of the Ancient Near East. Chichester: Wiley: Blackwell.

Baldi, J. 2012. Coba bowls, mass production and social change in Post-Ubaid times. Pp. 393-413 in C. Marro (ed.), After the Ubaid: Interpreting Change from the Caucasus to Mesopotamia at the Dawn of Urban Civilization (4500-3500 BC). Paris: De Boccard.

Barth, F. 1953. Principles of Social Organization in Southern Kurdistan. Oslo: Brødrene Jørgensen.

Boese, J. 1995. Ausgrabungen in Tell Sheikh Hassan I. Vorläufige Berichte über die Ausgrabungskampagnen 198490 und 1992-94. Saarbrücken: Saarbrücker Druckerei und Verlag.

Boivin, N., D.Q. Fuller and A. Crowther. 2012. Old World globalization and the Columbian exchange: comparison and contrast. World Archaeology 44(3): 452-69.

Campbell, S. 2007. Rethinking Halaf chronologies. Paléorient 33: 103-36.

- 2012. Northern Mesopotamia. Pp. 415-30 in D.T. Potts (ed.), A Companion to the Archaeology of the Ancient Near East. Chichester: Wiley: Blackwell.

Campbell, S., E. Carter, E. Healey, S. Anderson, A. Kennedy and S. Whitcher. 1999. Emerging complexity on the Kahramanmaraş Plain, Turkey: The Domuztepe Project 1995-1997. American Journal of Archaeology 103: 395-418.

Carter, R. and G. Philip (eds.). 2010. Beyond the Ubaid: Transformation and Integration in the Late Prehistoric Societies of the Middle East. Studies in Ancient Oriental Civilization 63. Chicago, Ill.: Oriental Institute of the University of Chicago. 
Copeland, L. 1989. The flint and obsidian artefacts at Tell Sabi Abyad. Pp. 81-119 in P.M.M. Akkermans (ed.), Excavations at Tell Sabi Abyad. Prehistoric Investigations in the Balikh Valley, Northern Syria. Oxford: British Archaeological Reports International Series.

Edens, C. 1999. The chipped stone industry at Hacinebi: technological styles and social identity. Paléorient 25: 23-33.

Evershed, R.P., S. Payne, A.G. Sherratt, M.S. Copley, J. Coolidge. 2008. Earliest date for milk use in the Near East and southeastern Europe linked to cattle herding. Nature 455: 528-31.

Fahmy, A.G., R. Friedman and M.A. Fadl. 2011. Economy and ecology of Predynastic Hierakonpolis, Egypt: archaeobotanical evidence from a trash mounds at HK11C. Pp. 91-118 in A.G. Fahmy, S. Kahlheber and A.C. D'Andrea (eds.), Windows on the African Past. Current Approaches to African Archaeobotany. Frankfurt: Africa Magna Verlag.

Fiorina, P. and G.M. Bulgarelli. 1985. Tell Hassan. Pp. 28-36 in La terra tra I due fiumi. Venti anni de archeologia italiana in Medio Oriente. La Mesopotamia dei tesori. Exhibition catalogue. Turin: Alessandri.

Gopnick, H. and M. Rothman (eds.) 2011. On the High Road: the History of Godin Tepe, Iran. Costa Mesa: Mazda Publishers.

Goulder, J. 2010. Administrators' bread: an experiment-based re-assessment of the functional and cultural role of the Uruk bevel-rim bowl. Antiquity 84: 351-62.

Gut, R. 1995. Das Prähistorische Ninive. Zur relative Chronologie der frühen Perioden Nordmesopotamiens. Mainz am Rhein: von Zabern.

Healey, E. 2000. The Role of Obsidian in the Late Halaf. Unpublished PhD Thesis, University of Manchester.

Henrickson, E.F. 1989. Stylistic similarity and cultural interaction between the 'Ubaid tradition and the Central Zagros highlands. Pp. 369-404 in E.F. Henrickson and I. Thuesen (eds.), Upon This Foundation. The 'Ubaid Reconsidered. Copenhagen: Carsten Niebuhr Institute.

Hijjara, I. 1997. The Halaf period in northern Mesopotamia. London: Nabu.

Jasim, S.A. 1985. The Ubaid Period in Iraq: Recent Excavations in the Hamrin Region. Oxford: British Archaeological Reports.

Kansa, S.W., A. Kennedy, S. Campbell and E. Carter. 2009. Resource exploitation at Late Neolithic Domuztepe. Current Anthropology 50 (6): 897-914.

Kepinski, C. 2011. New evidence from Grai Resh, northern Iraq-the 2001 and 2002 seasons. A pre-Uruk expansion site from the Late Chalcolithic Period. Zeitschrift für Orient-Archäologie 4: 46-101.

McCorriston, J. 1992. The Halaf environment and human activities in the Khabur drainage. Journal of Field Archaeology 19 (3): 315-33.

- 1997. The fiber revolution: textile extensification, alienation, and social stratification in ancient Mesopotamia. Current Anthropology 38 (4): 517-35.

Maeda, O. 1998. Chipped and Ground Stone Artifacts. Pp. 86-108 in A. Tsuneki and Y. Miyake (eds.), Excavations at Tell Umm Qseir in Middle Khabur Valley, North Syria: Report of the 1996 Season. Department of Archaeology, University of Tsukuba.

Mallowan, M.E.L. and J.C. Rose. 1935. Excavations at Tall Arpachiyah, 1933. Iraq 2(1): 1-178.

Marro, C. 2012. Is there a Post-Ubaid culture? Reflections on the transition from the Ubaid to the Uruk periods along the Fertile Crescent and beyond. Pp. 13-38 in C. Marro (ed.), After the Ubaid: Interpreting Change from the Caucasus to Mesopotamia at the Dawn of Urban Civilization (4500-3500 BC). Paris: De Boccard.

Matthews, R., W. Matthews and Y. Mohammadifar (eds.). 2013. The Earliest Neolithic of Iran: 2008 Excavations at Sheikh-e Abad and Jani. Oxford: Oxbow Books.

Merpert, N.Y. and R.M. Munchaev. 1993. Yarim Tepe II: The Halaf Levels. Pp. 129-62 in N. Yoffee and J.J. Clark (eds.), Early Stages in the Evolution of Mesopotamian Civilization. Soviet Excavations in Northern Iraq. Tuscon \& London: The University of Arizona Press.

Miglus, P.A., U. Bürger, M. Heil, and F. Stepniowski. 2011. Ausgrabung in Bakr Āwa 2010. Zeitschrift für Orient-Archäologie 4: 136-74.

Miglus, P.A., U. Bürger, R.A. Fetner and S. Mühl. 2013. Excavation at Bakr Awa 2010 and 2011. Iraq 75: 43-88.

Miller, N.F. 1991. The Near East. Pp. 133-60 in W.A. Van Zeist, K. Wasylikowa and K.-E. Behre (eds.), Progress in Old World Palaeoethnobotany. Rotterdam: A. A. Balkema.

Moon, J. and M. Roaf. 1984 The pottery from Tell Madhhur. Sumer 43: 108-67.

Motuzaite-Matuzeviciute, G., R.A. Staff, H.V. Hunt, X. Liu and M.K. Jones. 2013. The early chronology of broomcorn millet (Panicum miliaceum) in Europe. Antiquity 87 (338): 1073-85.

Mühl, S. 2010. Durchs wilde Kurdistan. Neue Forschungen in der Provinz Sulaimaniya, Irak. Agora 1: 48-53

- 2013. Siedlungsgeschichte im mittleren Osttigrisgebiet, Vom Neolithikum bis in die neuassyrische Zeit. Abhundlungen der Deutschen Orient-Gesellschaft 28. Wiesbaden: Harrassowitz Verlag.

Nieuwenhuyse, O., K. Berghuijs and S. Mühl. 2012. A late Neolithic "fishing net" from Kurdistan, northern Iraq? Paléorient 38: 141-47. 
Nieuwenhuyse, O., T. Odaka, A. Kaneda, S. Mühl, K. Rasheed, M. Altaweel. 2016. Revisiting Tell Begum: a prehistoric site in the Shahrizor Plain, Iraqi Kurdistan. Iraq 78: 103-35.

Oates, D., J. Oates and H. McDonald. 1997. Excavations at Tell Brak. Vol. I: The Mitanni and Old Babylonian Periods. British School of Archaeology in Iraq: London.

Oates, J. 1993. Trade and power in the fifth and fourth millennia BC: new evidence from northern Mesopotamia. World Archaeology 24: 403-22.

2012. The Terminal Ubaid (LC 1) level at Tell Brak. Pp. 66-86 in C. Marro (ed.), After the Ubaid: Interpreting Change from the Caucasus to Mesopotamia at the Dawn of Urban Civilization (4500-3500 BC). Paris: De Boccard.

Parker, B. and C. Foster. 2009. An overview of the ceramic sequence at Kenan Tepe. Pp. 505-31 in H. Sağlatimur, Z. Derin and E. Abay (eds.), Studies in Honour of Altan Çilingiroglu: A Life Dedicated to Urartu on the Shores of the Upper Sea. Istanbul: Arkeoloji ve Sanat Yayinlari.

Potts, D.T. 2014. Nomadism in Iran: from Antiquity to the Modern Era. New York: Oxford University Press.

Renette, S. forthcoming. Preliminary results from excavations at Kani Shaie, southern Bazyan Valley (Sulaimaniyah, Iraqi Kurdistan). In Kopanias, K. and J. MacGinnis (eds.), Archaeological Research in the Kurdistan Region of Iraq and Adjacent Areas. Oxford: Archaeopress.

Roaf, M. 1989. Ubaid social organization and social activities as seen from Tell Madhhur. Pp. 91-146 in E.F. Henrickson and I. Thuesen (eds.), Upon This Foundation. The 'Ubaid Reconsidered. Copenhagen: Carsten Niebuhr Institute.

Rosen, S. 1983. The Canaanean Blade and the Early Bronze Age. Israel Exploration Journal 33: 15-29.

Rothman, M.S. 2001. The Tigris Piedmont, Eastern Jezira, and Highland Western Iran in the fourth millennium BC. pp. 349-402 in M.S. Rothman (ed.), Uruk Mesopotamia and its Neighbours: Cross-Cultural Interactions in the Era of State Formation. Santa Fe, Oxford: School of American Research Press and James Currey.

- 2002a. Tepe Gawra: chronology and socio-economic change in the foothills of northern Iraq in the era of state formation. Pp. 49-77 in N. Postgate (ed.), Artefacts of Complexity: Tracking the Uruk in the Near East. London: British School of Archaeology in Iraq.

- 2002b. Tepe Gawra: the Evolution of a Small, Prehistoric Center in Northern Iraq. (University Museum Monograph 112). Philadelphia (PA): University of Pennsylvania Museum of Archaeology and Anthropology.

- 2013. Interpreting the role of Godin Tepe in the "Uruk expansion". Pp. 75-92 in C. Petrie (ed.), Ancient Iran and its Neighbours: Local Developments and Long-Range Interactions in the Fourth Millennium BC. Oxford: Oxbow Books.

Rothman, M. and V. Badler. 2011. Contact and development in Godin Period VI. Pp. 67-137 in H. Gopnick, H. and M. Rothman (eds.), On the High Road: the History of Godin Tepe, Iran. Mazda Publishers Inc.: Costa Mesa.

Schwartz, G. and P.M.M.G. Akkermans. 2003. The Archaeology of Syria: from Complex Hunter-Gatherers to Early Urban Societies (c. 16,000-300 BC). Cambridge: Cambridge University Press.

Sherratt, A.G. 1997. Economy and Society in Prehistory Europe. Edinburgh: Edinburgh University Press.

Spataro, M. and A. Fletcher. 2010. Centralisation or regional identity in the Halaf period? Examining interactions within fine painted ware production. Paléorient 36: 91-116.

Starr, R.F.S. 1937-39. Nuzi. Report on the Excavation at Yorgan Tepe near Kirkuk, Iraq / Conducted by Harvard University in conjunction with the American Schools of Oriental Research and the University Museum of Philadelphia, 1927-1931. Cambridge, Mass: Harvard University Press.

Tobler, A.J. 1950. Excavations at Tepe Gawra, Volume II: Levels IX-XX. University of Pennsylvania Press: Philadelphia.

Valamoti, S.M. 2013. Millet, the latecomer: on the tracks of Panicum miliaceum in prehistoric Greece. Archaeological and Anthropological Sciences, 1-13.

Van Zeist, W. and J.A.H. Bakker-Heeres. 1984. Archaeobotanical studies in the Levant, 2. Neolithic and Halaf levels at Ras Shamra. Palaeohistoria 26: 151-70.

von Wickede, A. 1990. Prähistorische Stempelglyptik in Vorderasien. Munich: Profil Verlag.

Watson, P.J. 1983. The soundings at Banahilk. Pp. 545-613 in L.S. Braidwood, R. Braidwood, B. Howe, C.A. Reed, and P.J. Watson (eds.), Prehistoric Archaeology along the Zagros Flanks. Chicago: University of Chicago.

Wengrow, D. 1998. 'The changing face of clay': continuity and change in the transition from village to urban life in the Near East. Antiquity 72 (278): 783-95.

- 2001. The evolution of simplicity: aesthetic labour and social change in the Neolithic Near East. World Archaeology 33 (2): 168-88.

-2010. What Makes Civilisation? The Ancient Near East and the Future of the West. Oxford: Oxford University Press. 
Wilkinson., T.C. 2014. The Early Transcaucasian phenomenon in structural-systemic perspective: cuisine, craft, and economy. Paléorient 40 (2): 203-29.

Wilkinson, T.J. 2003. Archaeological Landscapes of the Near East. Tucson, AZ: University of Arizona Press.

Wilkinson, T.J., B.H. Monahan and D.J. Tucker. 1996. Khanijdal East: a small Ubaid site in Northern Iraq. Iraq 58: $17-50$.

Wilkinson, T.J. and D.J. Tucker. 1995. Settlement Development in the North Jazira, Iraq: a Study of the Archaeological Landscape. Warminster: Published for the British School of Archaeology in Iraq and the Department of Antiquities \& Heritage, Baghdad, by Aris \& Phillips.

Zeder, M.A. and B. Hesse. 2000. The initial domestication of goats (Capra hircus) in the Zagros Mountains 10,000 years ago. Science 287: 2254-57.

Zohary, D., M. Hopf, and E. Weiss. 2012. Domestication of Plants in the Old World: The Origin and Spread of Domesticated Plants in Southwest Asia, Europe, and the Mediterranean Basin. Oxford: Oxford University Press.

David Wengrow

UCL Institute of Archaeology

31-34 Gordon Square

London WC1H OPY

d.wengrow@ucl.ac.uk

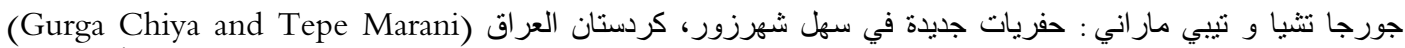

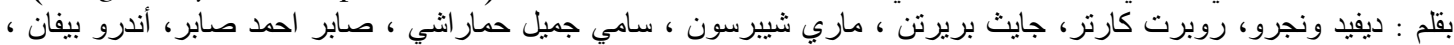

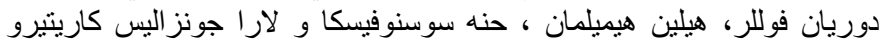

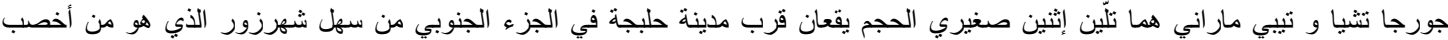

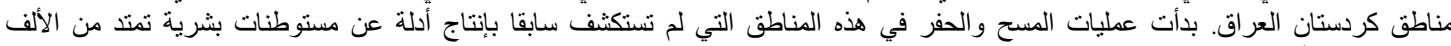

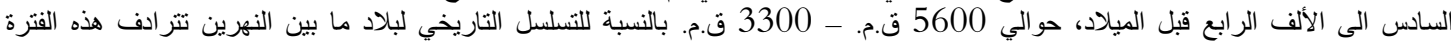

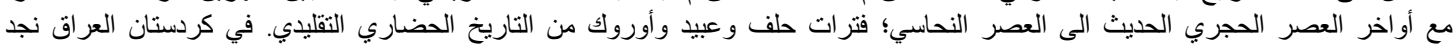

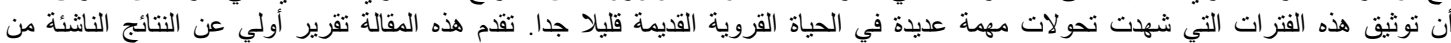

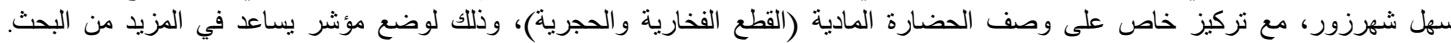

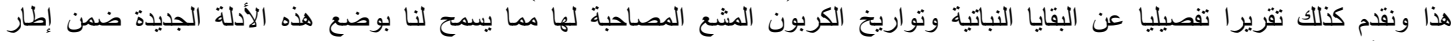

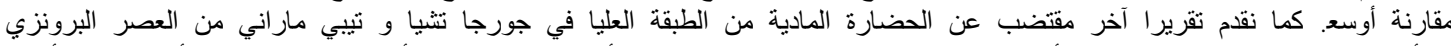

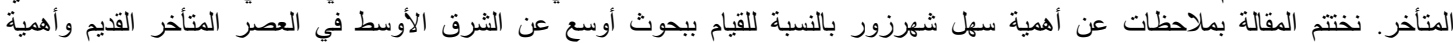
المحافظة على سجلاته الأثرية والتحري فئها. 